\title{
Feasible metabolisms in high pH springs of the Philippines
}

\author{
Dawn Cardace ${ }^{1 *}$, D'Arcy R. Meyer-Dombard $^{2}$, Kristin M. Woycheese ${ }^{2}$ and Carlo A. Arcilla ${ }^{3}$ \\ ${ }^{1}$ Microbe Mineral Interactions Laboratory, Department of Geosciences, University of Rhode Island, Kingston, RI, USA \\ ${ }^{2}$ Ecosystem Dynamics in Geochemical Environments Lab, Department of Earth and Environmental Science, University of Illinois at Chicago, Chicago, IL, USA \\ ${ }^{3}$ National Institute of Geological Sciences, College of Science, University of the Philippines, Diliman, Quezon City, Philippines
}

\author{
Edited by: \\ Jennifer F. Biddle, University of \\ Delaware, USA \\ Reviewed by: \\ Doug LaRowe, University of \\ Southern California, USA \\ William Brazelton, East Carolina \\ University, USA \\ ${ }^{*}$ Correspondence: \\ Dawn Cardace, Department of \\ Geosciences, University of Rhode \\ Island, 9 E. Alumni Avenue, 317 \\ Woodward Hall, Kingston, RI 02881 , \\ USA \\ e-mail: cardace@mail.uri.edu
}

\begin{abstract}
A field campaign targeting high $\mathrm{pH}, \mathrm{H}_{2}$, and $\mathrm{CH}_{4}$-emitting serpentinite-associated springs in the Zambales and Palawan Ophiolites of the Philippines was conducted in 2012-2013, and enabled description of several springs sourced in altered pillow basalts, gabbros, and peridotites. We combine field observations of $\mathrm{pH}$, temperature, conductivity, dissolved oxygen, and oxidation-reduction potential with analyses of major ions, dissolved inorganic carbon, dissolved organic carbon, and dissolved gas phases in order to model the activities of selected phases important to microbial metabolism, and to rank feasible metabolic reactions based on energy yield. We document changing geochemical inventories in these springs between sampling years, and examine how the environment supports or prevents the function of certain microbial metabolisms. In all, this geochemistry-based assessment of feasible metabolisms indicates methane cycling, hydrogen oxidation, some iron and sulfur metabolisms, and ammonia oxidation are feasible reactions in this continental site of serpentinization.
\end{abstract}

Keywords: serpentinization, Philippines Islands, high pH springs, ultramafic, geochemical modeling, microbial metabolisms

\section{INTRODUCTION}

Scientific understanding of biosphere-geosphere interactions in Earth's deep subsurface habitats is incomplete. In general, it has been estimated that this deep biosphere could accommodate up to $2 \times 10^{14}$ tons of biomass, which would represent more biomass than on Earth's surface (Gold, 1992; Whitman et al., 1998); more recently, this biomass has been estimated as far less, based on data from diverse subseafloor habitats (Jorgensen, 2012; Kallmeyer et al., 2012). The impact that this reservoir of biomass has on biogeochemical cycling on and in Earth is little known.

Recent characterizations of seabed vents and continental springs hosted in ultramafic (i.e., very Fe- and Mg-rich) rocks provided new insight into a previously little described aspect of the deep biosphere (see site summaries and references in Table 1). The mineralogy of these rocks differentiates them from classic black or white smoker systems in the seabed and similar hydrothermal systems on land. Whereas the chemistry and microbial ecology associated with black and white smoker systems are tied to the reaction of circulating seawater with minerals of the oceanic crust, ultramafic minerals constitute the deeper, mantletype rock unit, with correspondingly higher proportions of the mineral olivine. The reaction of seawater and/or meteoric water with olivine drives mineral transformations in the ultramafic regions of the seabed and continental subsurface, generating chemical energy that has the potential to sustain hidden microbial ecosystems that extend beneath seabed vents and continental springs.

With the addition of water, fayalite (iron-rich olivine, $\mathrm{Fe}_{2} \mathrm{SiO}_{4}$ ), forsterite (magnesium-rich olivine, $\mathrm{Mg}_{2} \mathrm{SiO}_{4}$ ), and pyroxene [here taken as $(\mathrm{Na}, \mathrm{Ca})(\mathrm{Mg}, \mathrm{Fe}, \mathrm{Al}) \mathrm{Si}_{2} \mathrm{O}_{6}$ ] in ultramafic rocks can react to form serpentine minerals (e.g., lizardite, chrysotile, and antigorite), hydroxides, and associated phases (Prichard, 1979), as shown in reaction (1).

$$
\begin{aligned}
\mathrm{Fe}_{2} \mathrm{SiO}_{4}+5 \mathrm{Mg}_{2} \mathrm{SiO}_{4}+9 \mathrm{H}_{2} \mathrm{O} \rightarrow & 3 \mathrm{Mg}_{3} \mathrm{Si}_{2} \mathrm{O}_{5}(\mathrm{OH})_{4} \\
& +\mathrm{Mg}(\mathrm{OH})_{2}+2 \mathrm{Fe}(\mathrm{OH})_{2}
\end{aligned}
$$

Fayalite + forsterite + water $\rightarrow$ serpentine + brucite

$$
+ \text { iron hydroxide }
$$

During dissolution of minerals in mafic and ultramafic rocks, protons $\left(\mathrm{H}^{+}\right)$are consumed, and eventually the dominant hydroxide ions drive up the $\mathrm{pH}$ of the aqueous system, producing the very high $\mathrm{pH}$ values $(>11)$ observed in actively serpentinizing systems. Concurrently, hydrogen is generated from reaction of the rock assemblage, when $\mathrm{Fe}^{2+}$ in $\mathrm{Fe}(\mathrm{OH})_{2}$ from (1) is oxidized to magnetite, coupled to the reduction of water, as in reaction (2).

$$
3 \mathrm{Fe}(\mathrm{OH})_{2} \rightarrow \mathrm{Fe}_{3} \mathrm{O}_{4}+2 \mathrm{H}_{2} \mathrm{O}+\mathrm{H}_{2}
$$

$\mathrm{H}_{2}$ is a well described and well utilized fuel for biological metabolism (Jannasch and Mottl, 1985; Orphan and Hoehler, 2011; Petersen et al., 2011). The $\mathrm{H}_{2}$ yield from serpentinization is a critical driver of microbial ecosystems in ultramafic-associated environments (Sleep et al., 2004; Cardace and Hoehler, 2009; McCollom and Seewald, 2013; Schrenk et al., 2013), with compelling relevance also to life on the Early Earth (Russell et al., 2010, 2013) and astrobiology (Schulte et al., 2006; Ehlmann et al., 2011; Hellevang et al., 2011; Chassefiere et al., 2013; Lammer et al., 2013; Viviano et al., 2013). The total yield of $\mathrm{H}_{2}$ is constrained by parent rock characteristics such as Fe content and 
Table 1 | Summary of sites of ongoing research into the geobiology of ultramafic rocks.

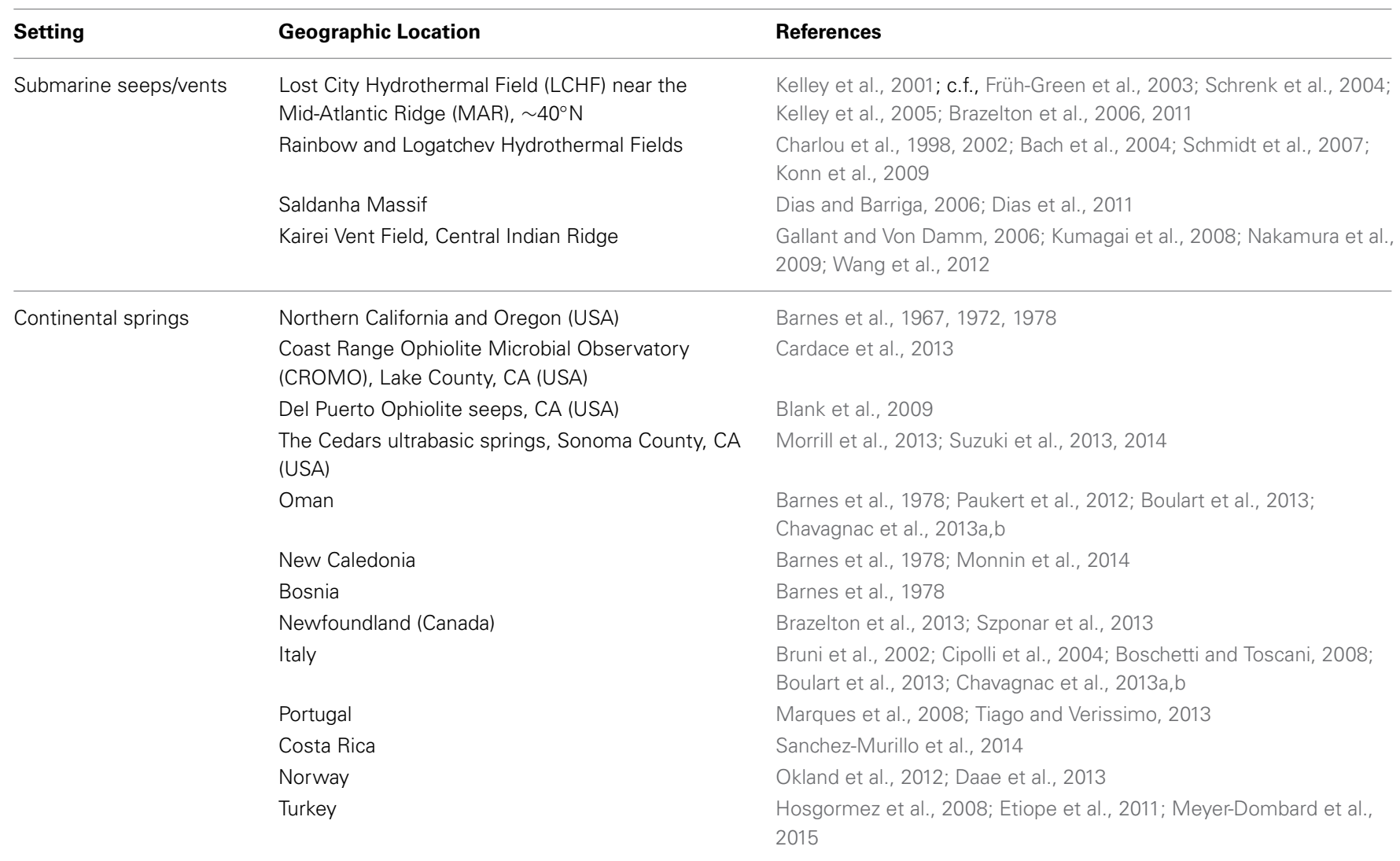

partitioning (McCollom and Bach, 2009; Klein et al., 2009). $\mathrm{H}_{2}$ can be used in chemotrophic energy production for fixation of $\mathrm{CO}_{2}$ into biomass by a diverse range of microorganisms, and is thus has excellent life-supporting potential in environments lacking light or abundant organic matter. Many $\mathrm{H}_{2}$-dependent metabolisms deliver large bioenergetic yields (Amend and Shock, 2001; Amend et al., 2011), and several deep biosphere environments on Earth are postulated to have metabolic chains dependent on similar lithogenic $\mathrm{H}_{2}$ (Chapelle et al., 2002; Nealson et al., 2005; D'Hondt, 2013).

Methane, formate, and modest amounts of acetate are all known geochemical products of serpentinization (Russell et al., 2010) and are likely important to the deep biosphere of serpentinites. In zones of active serpentinitzation in the deep seabed, for example, $\mathrm{CO}_{2}$, supplied by hydrologic connection to the global ocean, is thought to be reduced by $\mathrm{H}_{2}$, yielding formate and methanol (Seewald et al., 2006). Reducing the compounds further to produce methane or higher hydrocarbons likely requires metal alloy catalysts (Horita and Berndt, 1999; Proskurowski et al., 2008; Russell et al., 2010; Etiope and Ionescu, 2014). In fact, chemolithoautotrophy in mixing zones between ultramafic rockhosted hydrothermal systems and seawater has been supported by geochemical modeling; hydrogen oxidation, methanotrophy, sulfate reduction, and methanogenesis are all feasible given this environment (McCollom, 2007).

Additionally, active serpentinization of ultramafic rocks creates distinctive geochemical characteristics in related formation fluids and groundwaters, conventionally sorted by major ion chemistry into Type I and Type II waters (Neal and Stanger, 1984, 1985). Type I waters are produced when meteoric water infiltrates shallow aquifers of ultramafic rock in a so-called open system, that has incoming, ample dissolved $\mathrm{CO}_{2}$ derived from the atmosphere; $\mathrm{Mg}^{2+}$ from country rock is the major cation, and $\mathrm{HCO}_{3}^{-}$ is the major anion, and these are also titled $\mathrm{Mg}^{2+}-\mathrm{HCO}_{3}^{-}$waters. Type II waters are produced when Type I waters are isolated from/closed to the atmosphere, continue to react with country rock, and deposit stable Mg-rich secondary minerals such as serpentine, hydroxides, and some carbonates while $\mathrm{Ca}^{2+}$ remains dissolved; residual $\mathrm{Ca}^{2+}$ from country rock is the major cation, and the loss of protons (they are taken up by country rock) leaves a high activity of $\mathrm{OH}^{-}$, and these are termed $\mathrm{Ca}^{2+}-\mathrm{OH}^{-}$waters. Globally, land-based springs sourced in ultramafic rocks exhibit a range in $\mathrm{pH}$ values and ion chemistry, with $\mathrm{pH}$ values up to $>12$ and Ca:Mg ratios up to $~ 600: 1$ (c.f., Barnes et al., 1967, 1978).

In this work, we characterize the aqueous geochemistry of springs sourced in mafic-ultramafic units of the Zambales and Palawan Ophiolites (tectonically uplifted oceanic lithosphere, comprising mantle rocks, oceanic crust, and marine sediments) in the Philippines, and integrate these data into a model of feasible, co-occurring metabolic strategies that can be supported, based on the geochemistry of these systems. New microbiological findings related to Philippines high $\mathrm{pH}$ springs are coupled to the work described here (Woycheese et al., 2015). 


\section{GEOLOGIC SETTING}

The Philippines archipelago straddles a complex set of tectonically dissected microplates sandwiched between the Manila and Philippine Trenches, driven by the meeting of the Philippine and Eurasian tectonic plates. The Zambales Ophiolite in western Luzon features a well preserved ophiolite assemblage exposing mantle peridotite, deep crustal gabbro, ocean crust pillow basalts that solidified on the seafloor, and marine sedimentary formations (Evans and Hawkins, 1989). This ophiolite complex has an area of $\sim 160 \mathrm{~km}$ by $40 \mathrm{~km}$, with clearly recognizable units of Eocene Age oceanic crust and mantle-derived rocks, thought to have been emplaced in the Oligocene to Early Miocene, based on stratigraphic studies (Aurelio and Pena, 2010). Cretaceous age rocks of the Palawan Ophiolite crop out in the vicinity of San Isidro Spring (SI1) and Mainit Falls Spring (MF1), comprising a heavily tectonized, $30 \mathrm{~km}$ by $300 \mathrm{~km}$ swath of uplifted oceanic crust, likely emplaced in the Eocene, with extensive outcrops of seafloor rock types, such as sandstones, cherts, basalts, gabbros, and both olivineand pyroxene-dominated mantle units (Aurelio and Pena, 2010).

Though gas-rich springs in Palawan are nearly undescribed in the literature (minor mention in Giggenbach and Poreda, 1993), previous work has suggested active serpentinization in Zambales Ophiolite ultramafic rocks in particular. For Zambales, concentrations and isotopic compositions of gases emanating from various related springs and seeps are consistent with a serpentinization origin: gases measured at several seeps at the Los Fuegos Eternos location in the Zambales region by Abrajano et al. (1988) indicate a $\mathrm{CH}_{4}: \mathrm{H}_{2}$ ratio of 55:42 in a dry gas seep and 13:8 in a water saturated sediment-the rest being an unresolved mixture of $\mathrm{N}_{2}$ and $\mathrm{CO}$, with the systems extremely low in $\mathrm{CO}_{2}$ as expected (Abrajano et al., 1988).

\section{MATERIALS AND METHODS \\ SAMPLING}

Serpentinite-associated waters were collected for geochemical analysis from 7 sites in the Zambales Ophiolite, ranging from artesian wells to travertine-depositing springs, and 2 springs in the Palawan Ophiolite. Sampling sites are identified in Figure 1; additional detail is provided in Figure 2. A YSI556 Multiparameter System was used to measure simultaneously in the field dissolved oxygen, $\mathrm{pH}$, conductivity, temperature, and oxidation-reduction potential. A portable field spectrophotometer (HACH DR 2800) with commercially available reagent ampules enabled quantification of redox-sensitive chemical species (e.g., nitrate, nitrite, sulfide, ammonia). Water samples for laboratory analysis were collected with triple-flushed syringes $(60-\mathrm{ml}$ volumes with luerlok tips; BD Medical No. 309653), and filtered through syringe filters or through $0.22 \mu \mathrm{m}$ pore size Millipore Sterivex PVDF filters, assisted by peristaltic pump. Filtered solutions dedicated for ion chromatography analyses were stored cold in clean, triplerinsed Nalgene bottles, while filtered waters dedicated for elemental analysis were stored in clean, acid-washed sampling bottles (caps were parafilmed in the field to minimize evaporation), and acidified with nitric acid for a final concentration of $\sim 2 \%$ nitric acid.

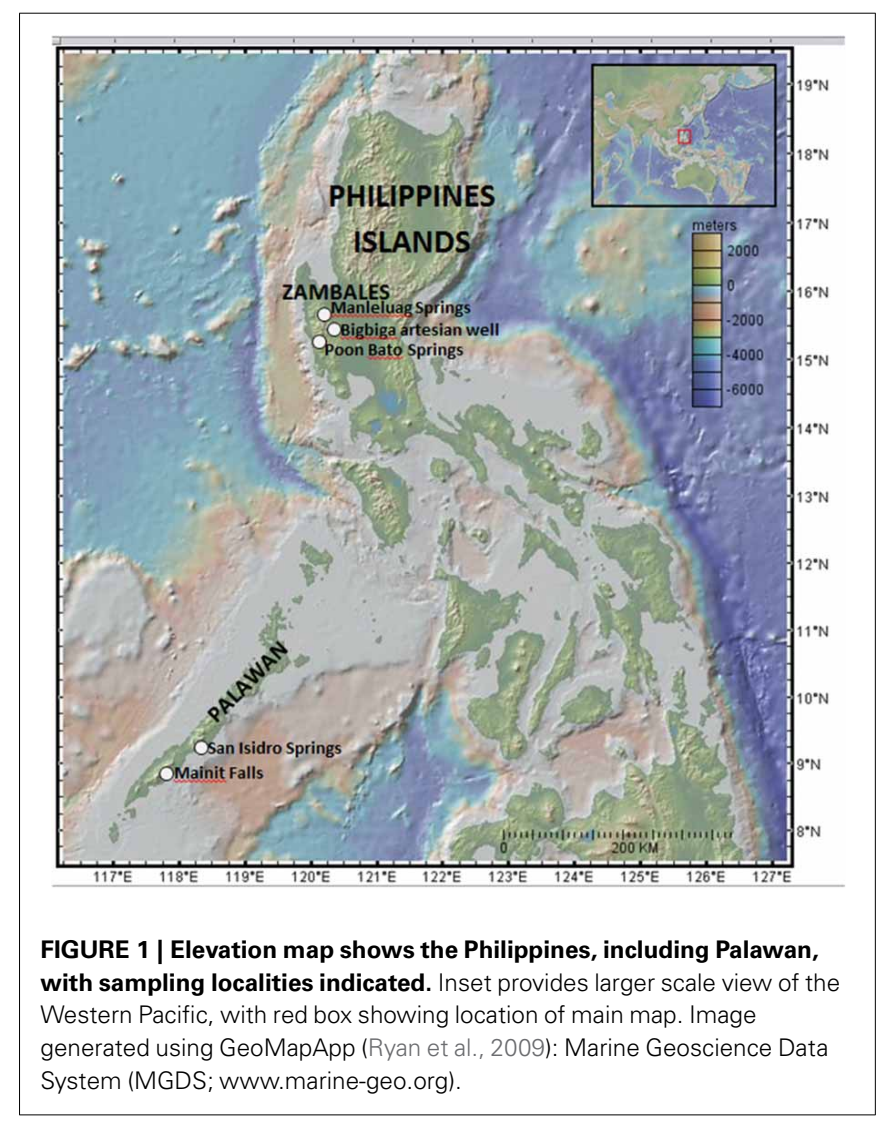

\section{AQUEOUS GEOCHEMISTRY}

For the 2012 field season, ions were characterized at Arizona State University (ASU). Samples for analysis of cations and anions were filtered into $60 \mathrm{ml}$ Nalgene bottles prepared by soaking overnight in an acid bath. Bottles were kept frozen until analysis. Samples for major ions were filtered in the field through a series of 0.8 and $0.2 \mu \mathrm{m}$ pore size filters (such as Supor filters made of hydrophilic polyether-sulfone, Pall Scientific). As quickly as possible after sampling, major cation $\left(\mathrm{Na}^{+}, \mathrm{K}^{+}, \mathrm{Ca}^{+2}, \mathrm{Mg}^{+2}\right)$, and anion $\left(\mathrm{SO}_{4}^{-2}\right.$, $\mathrm{Cl}^{-}, \mathrm{Br}^{-}, \mathrm{F}^{-}$) concentrations were measured in the laboratory using ion chromatography (anions: Dionex IonPac AS11 analytical and IonPac AG11 guard columns; cations: Dionex IonPac CS12A analytical and IonPac SG11 guard columns; conductivity detection). Analytical uncertainties are on the order of $5 \%$.

For the 2013 field season, concentrations of some major anions (chloride, bromide, nitrite, nitrate, phosphate, sulfate) were measured with a Dionex DX-120 ion chromatograph (University of Rhode Island, Kingston RI) outfitted with an IonPac AS22 Analytical Column $(4 \times 250 \mathrm{~mm})$ and IonPac AG22 Guard Column $(4 \times 50 \mathrm{~mm})$. A 5 point calibration was based on analysis of gravimetrically prepared calibration standards; calibration proved linear with $r^{2} \geq 0.999$ for all anions tested. Accuracy of data for $\mathrm{Cl}^{-}$is $\pm 3 \%$, for $\mathrm{NO}_{2}^{-}$is $\pm 5 \%, \mathrm{Br}^{-}$is $\pm 20 \%, \mathrm{NO}_{3}^{-}$ is $\pm 1 \%, \mathrm{PO}_{4}^{3-}$ is $\pm 1 \%, \mathrm{SO}_{4}^{2-}$ is $\pm 10 \%$, based on multiple analyses of the Dionex Seven Anion Standard (PN 056933; Lot Number 20-25VY).

Elemental concentration data were collected with a Thermo Scientific iCAP Q Inductively Coupled Plasma Mass Spectrometer 


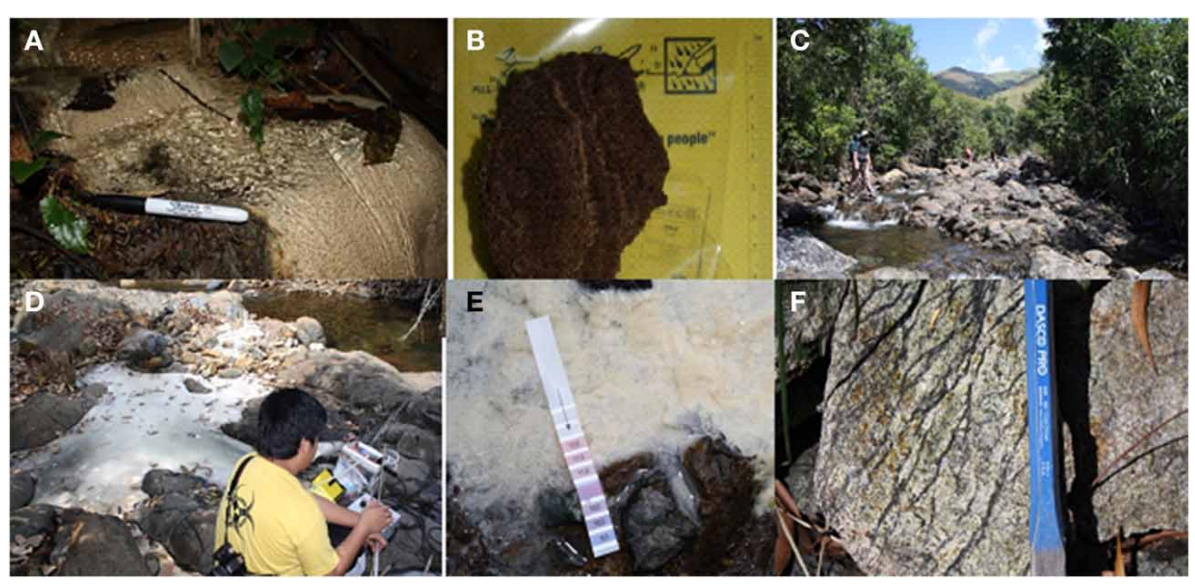

FIGURE 2 | (A) Active flowstone deposit near Manleluag Spring; terraces of travertine continued into/under the lushly vegetated adjacent landscape. (B) Within Manleluag Spring area, soft new travertine deposit. (C) Along the Poon Bato River. (D) Deeply sourced spring along
Poon Bato River(Site PB2), very basic, very reducing, and depositing travertine. (E) $\mathrm{pH}$ strip showing PB2 edge travertine surface with $\mathrm{pH} \sim 11$. (F) Serpentinite river cobble on the approach to Poon Bato River area springs. (housed in the Rhode Island IDeA Network for Excellence in Biomedical Research Lab). Calibration was made using the Ultra Scientific ICP-MS calibration standard \#2 (Cat.\#: IMS102, Ultra Scientific, North Kingstown, RI), presented to the instrument at concentrations of 100,500 , and $1000 \mathrm{ppb}$ in $2 \%$ nitric acid. Linear calibration across this concentration range was observed with $r^{2} \geq 0.999$ for all analytes except $\mathrm{Fe}(57)$, for which $r^{2} \geq$ 0.9875. An external reference solution (ICP-SS-50, High Purity Standards, Charleston, SC) was run as an unknown to assess accuracy, which differed by analyte. Uncertainty was observed as $\pm 10 \%$ for $\mathrm{Na}(23), \mathrm{Mg}(24), \mathrm{Al}(27), \mathrm{K}(39), \mathrm{V}(51), \mathrm{Cr}(52), \mathrm{Mn}(55)$, $\mathrm{Fe}(57), \mathrm{Co}(59), \mathrm{Ni}(60), \mathrm{Cu}(63), \mathrm{As}(75), \mathrm{Se}(82), \mathrm{Sr}(88)$; Ca(44) data carry a larger uncertainty of $\pm 30 \%$. Precision was typically $<1 \%$, as shown by very low relative standard deviations for triplicate analyses.

\section{STABLE ISOTOPES OF WATER}

Two milli liter volumes of filtered water were stored in vials with PTFE/silicone screw tops (Fisherbrand cat. no. 03-391-15) and analyzed with a Picarro Water Isotope Analyzer L1102i (Brown University Environmental Chemistry Facilities, Providence, RI). In practice, 2 microliters of liquid water were injected into the vaporizer module, which prepared and sent the sample to the laser cavity for measurement. Each sample was measured in triplicate and corrected for memory and drift (using the protocols of Vaughan and Claymore, INSTARR, Univ. of Colorado). All samples were measured with respect to internal lab standards, which were calibrated directly to VSMOW, SLAP and GISP2. Data are reported here with respect to VSMOW; overall precision and accuracy is better than $0.1 \% 0$ and $1.0 \%$ for $\delta^{18} \mathrm{O}$ and $\delta \mathrm{D}$, respectively.

\section{DISSOLVED INORGANIC CARBON (DIC) AND DISSOLVED ORGANIC CARBON (DOC)}

Sampling vials were amber I-CHEM vials. DIC septa were butyl/PTFE; DOC septa were silicone/PTFE. Prior to sampling,
DIC bottles and septa were acid-washed (overnight soak in 10\% $\mathrm{HCl}$ by volume solution, rinsed with high purity water of $\sim 18$ $\mathrm{M} \Omega$ resistivity), then dried and assembled. DOC bottles were combusted at $500^{\circ} \mathrm{C}$ overnight, septa were rinsed, then bottles were spiked with $100 \mathrm{ul}$ of ASC grade $85 \%$ phosphoric acid. In the field, all fluid was filtered. Collection bottle [not sampling bottle] was flushed with sample $3 \mathrm{x}$, as was tubing and syringe. DOC bottles were filled using a filter that had been conditioned with several liters of sample. Both DIC and DOC bottles were filled to the top with no air bubbles and kept at $\sim 20^{\circ} \mathrm{C}$ until analysis. DOC and DIC concentrations were measured with an OI Analytical Model 1010 Wet Oxidation Total Organic Carbon (TOC) Analyzer at ASU, as in Meyer-Dombard et al. (2015). Fluids were reacted with phosphoric acid (DIC) or sodium persulfate (DOC), and $\mathrm{CO}_{2}$ was analyzed by continuous flow into a Thermo Delta ${ }^{\text {Plus }}$ Advantage mass spectrometer. Three glycine working standards characterized with USGS40 and USGS41 isotopic reference materials were used that encompass expected isotopic variations (low: $\delta^{13} \mathrm{C}=-39.64 \% 0, \delta^{15} \mathrm{~N}=1.35 \% 0$; mid: $\delta^{13} \mathrm{C}=-8.36 \% 0, \delta^{15} \mathrm{~N}=$ 27.9\% ; and high: $\delta^{13} \mathrm{C}=15.67 \% 0, \delta^{15} \mathrm{~N}=51.8 \% 0$ ).

\section{GAS CHEMISTRY}

$10 \mathrm{~mL}$ serum vials and blue butyl stoppers were acid-washed (overnight soak in $10 \%$ by volume $\mathrm{HCl}$ and rinsed in $\sim 18 \mathrm{M} \Omega$ Milli-Q distilled water). Vials and stoppers were allowed to airdry, assembled, and crimped shut prior to flushing (Wheaton, Millville, NJ, USA). Gas sampling vials were flushed with Ar gas at a rate of $8-10$ psi pressure: briefly, a 23 gauge needle was inserted into the sealed vial, connected to a Luer-Lock-equipped tubing (BioRad Laboratories, Inc., Hercules, CA, USA) to the Ar tank. To ensure vials were not over-pressured, a venting needle attached to an open-ended $60 \mathrm{~mL}$ syringe filled with $10-15 \mathrm{~mL}$ of distilled water suspended above the gassing station to allow excess gas to vent without allowing atmospheric gas back into the vial. Flushed sampling vials were transported to the field, and filled with $5 \mathrm{~mL}$ of sample water using the following protocol: 
samples were collected with a syringe, and air bubbles were forced out of sample volume by depressing the syringe stopper. The sampling syringe was flushed $3 \mathrm{X}$, and samples were collected slowly to avoid the draw of vacuum. Samples were poisoned in the field with an $0.5 \mathrm{~mL}$ injection of $\mathrm{Hg}\left(\mathrm{NO}_{3}\right)_{2}(1.71 \mathrm{~g} / 50 \mathrm{~mL})$ and stored upside-down until analysis. Upon return to the USA, samples were immediately analyzed on a Shimadzu GC-2014 gas chromatograph/mass-spectrometer (GC-MS) equipped with flame ionization and thermal conductivity detectors (FID and TCD, respectively), a Carboxen ${ }^{\circledR} 1000$ 60/80 molecular sieve (Sigma-Aldrich Co., LLC, St. Louis, MO, USA), with a $1 / 8^{\prime \prime} \times 15^{\prime}$ column (Shimadzu Corporation, Kyoto, Japan). C1 gases of interest were first methanized (converted to $\mathrm{CH}_{4}$ ), combusted, and detected with the FID. $\mathrm{H}_{2}$ and Ar were detected on the TCD. Depending on sample concentration, 200-400 $\mu$ l of the gas in the sampling vial headspace were injected into the GC-MS column. Calibration curves were constructed using $\mathrm{H}_{2}, \mathrm{CO}, \mathrm{CH}_{4}$, and $\mathrm{CO}_{2}$ standard gases (Sigma-Aldrich Co., LLC, St. Louis, MO, USA), both during and 6 months after analysis; the calibration curves for all gases analyzed suggested that the GC-MS was stable and results were highly reproducible.

\section{GEOCHEMICAL MODELING}

Gibbs energy $\left(\Delta \mathrm{G}_{\mathrm{r}}\right)$ calculations were used to determine thermodynamically favorable reactions that can serve as microbial metabolisms supported by the environment under study. Gibbs energy calculations can be used to identify points in temperature-pressure-composition space where metabolisms are most favorable.

Values of $\Delta G_{r}$ at the temperature, pressure, and chemical composition at the sampled sites were computed with relation (3):

$$
\Delta G_{r}=\Delta G_{r}^{\circ}+R T \ln Q_{r}
$$

where $\Delta G_{r}^{\circ}$ denotes the standard state Gibbs energy values at the temperature and pressure of interest $\left(\Delta G_{r}^{\circ}\right.$ for chemical species pertinent to this work are readily available in Amend and Shock, 2001), $R$ represents the gas constant, $T$ represents temperature in Kelvin, and $Q_{\mathrm{r}}$ is the activity product.

$Q_{r}$, the activity product, can be computed from environmental data as shown in relation (4):

$$
Q_{r}=\Pi a_{i}^{v i, r}
$$

where $a_{i}$ represents the activity of the $i$ th species, and $v_{i}, r$ represents the stoichiometric reaction coefficient. Values of $a_{i}$ are generated from concentration data (Table 1) and are modified by normalization with reasonable activity coefficients, using the geochemical speciation code EQ3 (Wolery, 1992). In this code, activity coefficients are calculated using a variant (B-dot equation) of the Extended Debye-Hückel activity coefficient formalism (Helgeson, 1969), with reference to the SUPCRT92 (Johnson et al., 1992) thermodynamic database. Total dissolved solids (TDS) data, which must be known to quantify the ionic strength of the solution, were estimated from field conductivity data and included in EQ3 input files (see Supplementary Material). Note that EQ3 provides the equilibrium speciation of co-occurring geochemical components based on the data inputs. If data inputs lack a particular chemical species (e.g., acetate), EQ3 provides a rigorous estimate of its activity in the modeled environment, depending on thermodynamic constraints.

It is worth noting that $\Delta G_{r}^{\circ}$ can be calculated at the appropriate temperature and pressure for the aqueous species and minerals using established equations of state (Helgeson et al., 1978, 1981; Shock and Helgeson, 1988, 1990; Tanger and Helgeson, 1988; Shock et al., 1989, 1992), or computed from data for $\Delta G_{r}^{\circ}$ and $\Delta G_{i}^{\circ}$ at temperatures up to $200^{\circ} \mathrm{C}$ at $\mathrm{P}_{\text {sat }}$, available in Amend and Shock (2001). Conventionally, $\Delta G_{\mathrm{r}}^{\circ}$ can also be calculated from Gibbs energy of formation values, using relation (5):

$$
\Delta G_{r}^{\circ}=\Sigma v_{i, r} \Delta G_{i}^{\circ}
$$

In which $\Delta G_{r}^{\circ}$ is the standard state Gibbs energy of reaction $r, v_{i, r}$ is the stoichiometric reaction coefficient of the $i$ th species in reaction $r$, which is negative for reactants and positive for products, and $\Delta G_{i}^{\circ}$ is the standard Gibbs free energy of formation of the $i$ th species at the temperature and pressure of interest in reaction $r$.

\section{RESULTS}

\section{AQUEOUS GEOCHEMISTRY}

\section{Zambales ophiolite: Manleluag springs, Bigbiga artesian well, and Poon Bato springs}

In Zambales, the Manleluag Springs primary locality (ML1) is in a protected park area, with a bubbling spring housed in a sheltered cistern that feeds a set of community-accessible swimming pools. In adjacent undeveloped land, related spring water is emitted from a natural slope (ML2) and flows downhill through increasingly dense vegetation along a travertine-lined creek bed (ML3, encompasses sites CC1 and CC2 in Woycheese et al., 2015). Waters are of moderate to elevated $\mathrm{pH}$ (10-11), temperatures near $34^{\circ} \mathrm{C}$, and ORP values of -703 to $-245 \mathrm{mV}$ (corresponding to $\mathrm{Eh}$ ranging from -503 to $-45 \mathrm{mV}$, since there is a +200 correction required to transform observed ORP values to Eh when using the YSI556 ORP electrode kit) (Table 2). Sampling of country rock in the vicinity indicates gabbroic host rock to an unknown depth.

The Bigbiga Artesian Well (BB1) is a 30.5-m-deep artesian well that empties into a cistern. When opened, the cistern fills rapidly, providing perennial water access for the local community. Water is of $\mathrm{pH} 9.3$ and has a temperature of $30^{\circ} \mathrm{C}$, with an ORP value of $-146 \mathrm{mV}$ (corresponding to $\mathrm{Eh} \sim+54 \mathrm{mV}$ ) (Table 2). Well cores, property of co-author Arcilla, indicate that the base of the borehole is in altered pillow basalts overlain by bentonite, a fine-grained, clay-rich sedimentary formation; this site samples waters interacting with rocks equivalent to the top of the ocean crust.

Multiple springs are also located alongside the Poon Bato River, where associated travertine deposits are short-lived, destroyed/repositioned after small magnitude earthquakes and/or seasonally intense rainfalls. PB1 and PB2 are close to each other ( $<50 \mathrm{~m}$ distant) while PB3 is several $\mathrm{km}$ upstream. PB1 exhibited well-developed travertine in both sampling years. PB2 showed some loss in travertine extent between 2012 and 2013. PB3 was well developed in 2012, emanating at low flow rates about $5 \mathrm{~m}$ away from the Poon Bato River bank, causing deposition of 


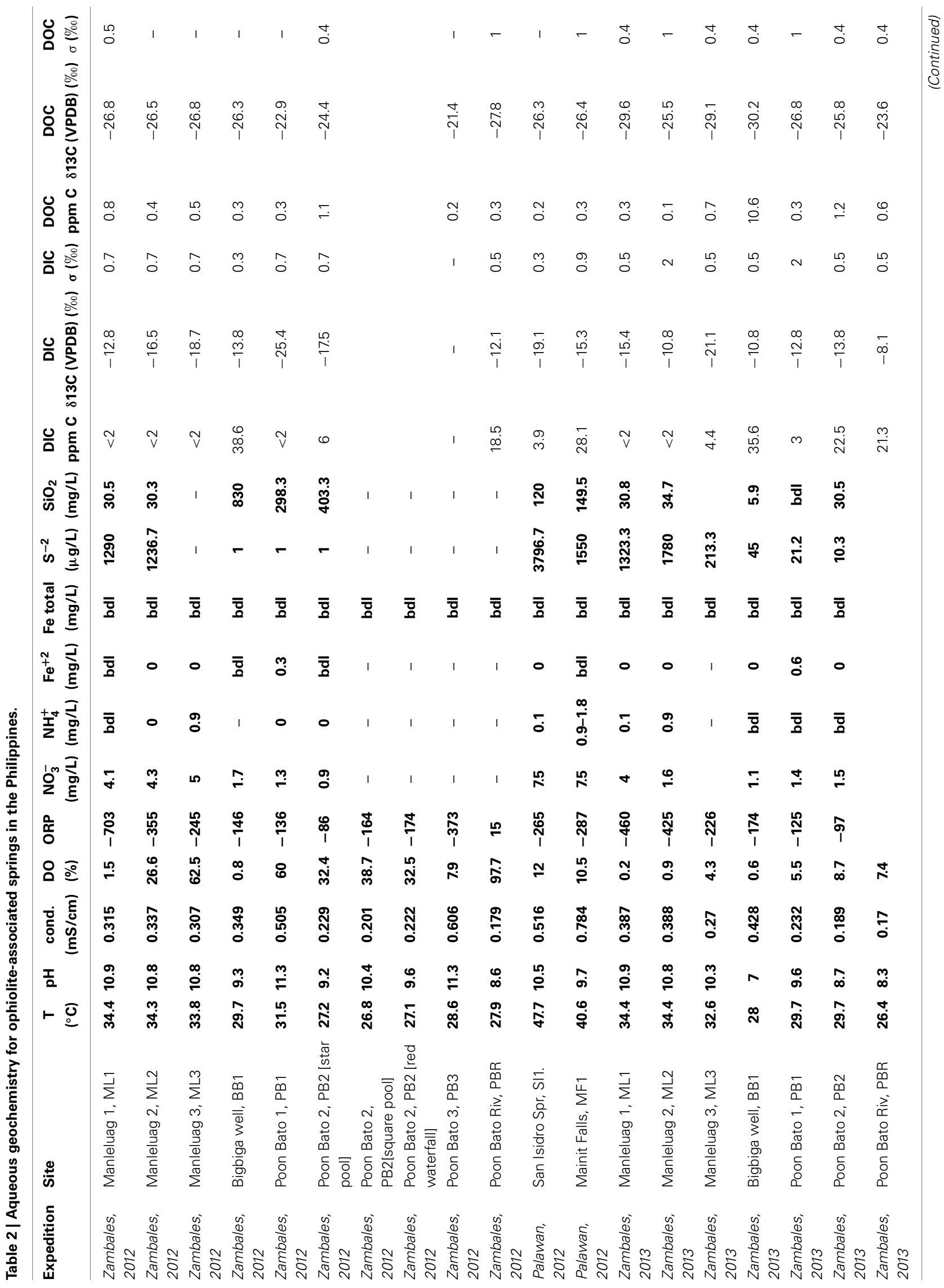




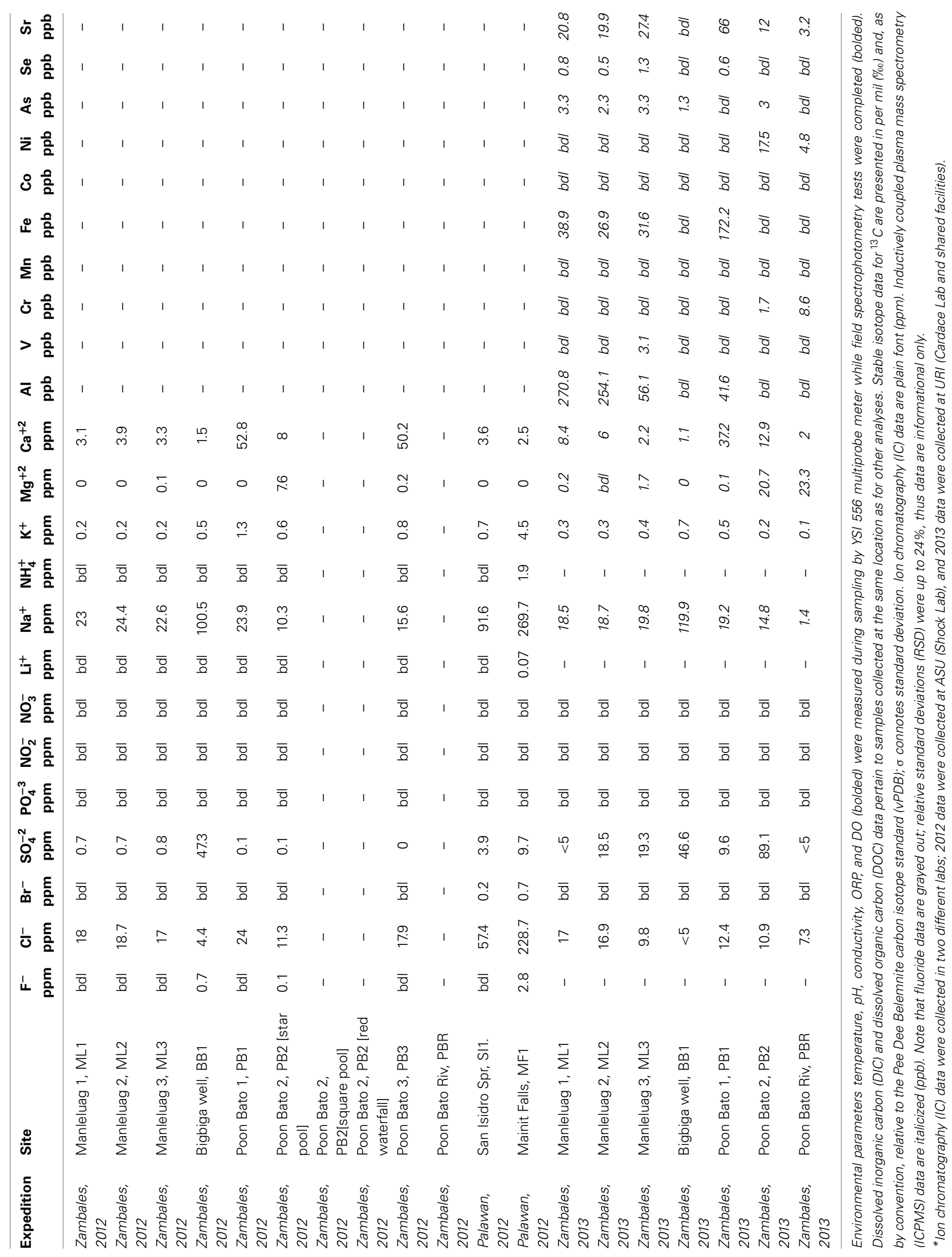


travertine along a winding $\sim 20$-meter-long path, ending at the river; this site was wiped out completely in 2013, with much loss of carbonate mineralization due to chemically aggressive rain waters in the intervening seasonal monsoons, which have been intense in recent years. Waters are of very high $\mathrm{pH}(>11$ at $\mathrm{PB} 1$ and $\mathrm{PB} 3$ ), with temperatures ranging from 27 to $32^{\circ} \mathrm{C}$, and ORP values of -373 to $-86 \mathrm{mV}$ (corresponding to Eh ranging from $\sim-173$ to $+114 \mathrm{mV}$ ) (Table 2 ). Sampling of country rock indicates that serpentinite (altered mantle rock) is the host rock.

\section{Palawan ophiolite: San Isidro spring and Mainit Falls spring}

Site SI1 is influenced by hydrothermally altered waters, bringing the surface water temperature to $47.7^{\circ} \mathrm{C}$, with 3 times more $\mathrm{Cl}^{-}$and almost 10 times more $\mathrm{Na}^{+}$than in seawater. Water is of elevated $\mathrm{pH}$ (10.5), with ORP observed at $-265 \mathrm{mV}$ (corresponding to Eh of $\sim-65 \mathrm{mV}$ ). Similarly, Site MF1 has numerous small sources of hydrothermally altered waters emptying into a main sampling pool with a temperature of $40.6^{\circ} \mathrm{C}$; waters exhibit an order of magnitude more $\mathrm{Cl}^{-}$and $\mathrm{Na}^{+}$than seawater (Table 2). Water is of elevated $\mathrm{pH}$ (9.7), with ORP observed at $-287 \mathrm{mV}$ (corresponding to Eh of $\sim-87 \mathrm{mV}$ ) (Table 2).

Overall, sampled springs exhibit strong (ML and $\mathrm{PB}$ sites) to weak (BB) serpentinization inputs and some hydrothermal inputs, creating a diversity of subsurface aqueous environments. Eh tracks inversely with $\mathrm{pH}$, and $\mathrm{Ca}^{2+}$ and $\mathrm{Cl}^{-}$both increase generally with $\mathrm{pH}$ (Figure 3). More evocative are the Stiff diagrams provided as a collection of panels in Figure 4, in which the major ion chemistry is charted to provide a geometric field that allows rapid visual identification of similar and different water types. From Figure 4, in terms of dissolved constituents, ML sites, $\mathrm{PB}$ sites, and $\mathrm{BB} 1$, are 3 distinct water types, and SI1 and MF1 constitute a fourth group. Despite these differences in dissolved constituents, stable isotope data for sampled waters shows that all new data fall near/on the local meteoric water line (LMWL) (see Figure 5, LMWL from Gerardo-Abaya, 2005). The LMWL is shown as a black, positive sloping line, tracking the variation in stable isotopes of oxygen and hydrogen in regional precipitation, as $\delta \mathrm{D}$ is known to have a linear relationship with $\delta^{18} \mathrm{O}$. When data for spring waters are far from the LMWL, they have experienced isotopic fractionation, perhaps through evaporation or interactions with magmatic processes (note how far from the LMWL are the triangle symbols, Figure 5). When spring waters fall on the
LMWL, as shown here in Figure 5, they are taken to be genetically related to regional precipitation. These data are not available for SI 1 and MF1, thus their source is unconstrained by this test.

\section{Dissolved inorganic and organic carbon (DIC and DOC)}

Table 2 presents dissolved inorganic carbon (DIC) data for these springs. ML and PB springs cluster together with SI1 at very low total DIC, with $\delta^{13} \mathrm{C}$ between -10 and $-26 \%$; though not unusual for groundwater values, together these data convey the variability in the DIC of those waters, apparently depleted to some degree with respect to regional Poon Bato River (PBR) samples, for which DIC was observed at $\sim 20 \mathrm{ppm}$ DIC, with $\delta^{13} \mathrm{C}$ between -8 and $-12 \%$. One $\mathrm{PB}$ spring data point falls near these surface river waters, suggesting mixing of a deeper, more isotopically light reservoir with surface, river-type waters. BB1 data fall near 40 ppm DIC and between -10 and $-15 \%$ $\delta^{13} \mathrm{C}$, and may represent waters strongly influenced by continuing metabasalt alteration. MF1, in between identified clusters, may be a mixture of more isotopically depleted water with BB1-type, metabasalt-hosted waters.

Dissolved organic carbon (DOC) data cluster together at $<2$ ppm DOC and between -22 and $-30 \% 0 \delta^{13} \mathrm{C}$, indicating a self-consistent DOC inventory that may transcend other site characteristics. The only exception is for BB1 in 2013, for which total DOC is elevated to near $10 \mathrm{ppm}$; this is likely due to some sample contamination with biofilms near the well outlet. In all cases, DOC is isotopically lighter than DIC, supporting either microbial carbon cycling in situ or contributions from another, isotopically very light, source of DOC such as infiltration from surface sources.

\section{GAS CHEMISTRY}

Waters can be grouped into four types based on dissolved gas constituents. ML1 and PB3 bear $\mathrm{CO}, \mathrm{CH}_{4}$, and $\mathrm{H}_{2}$. ML2, PB2, and SI bear $\mathrm{CO}_{2}, \mathrm{CH}_{4}$, and $\mathrm{H}_{2}$. $\mathrm{BB} 1$ is rich in $\mathrm{CO}_{2}$ only. MF1 had overall low gas contents, although $\mathrm{CH}_{4}$ was observed. Taken together, these springs cover a range in gas contents (Table 3, Figure 6).

Given that (a) gas contributions from a subsurface zone undergoing active serpentinization is expected to yield $\mathrm{H}_{2}$ and $\mathrm{CH}_{4}$ and (b) extremely high $\mathrm{pH}, \mathrm{Ca}^{2+}-\mathrm{OH}^{-}$waters are inherently poor in aqueous $\mathrm{CO}_{2}$ since they have been isolated from the atmosphere, and are thus poor in DIC, first order conclusions can be drawn
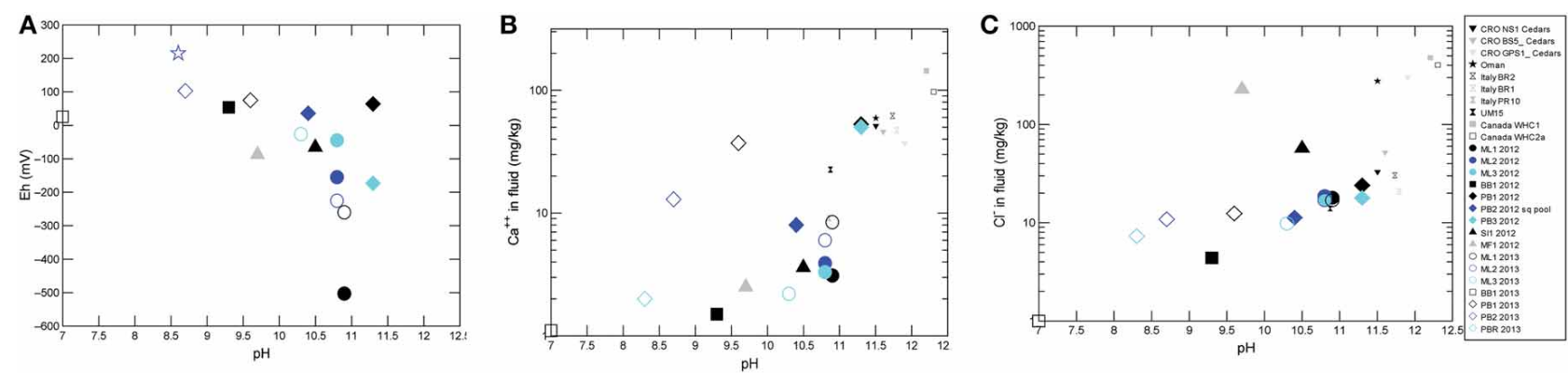

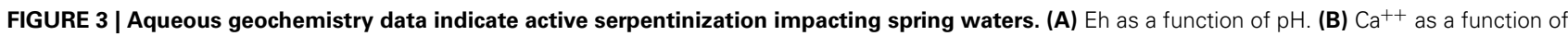
$\mathrm{pH}$. (C) $\mathrm{Cl}^{-}$as a function of $\mathrm{pH}$ for all sites sampled in this study, with other known continental sites of serpentinization for context. 

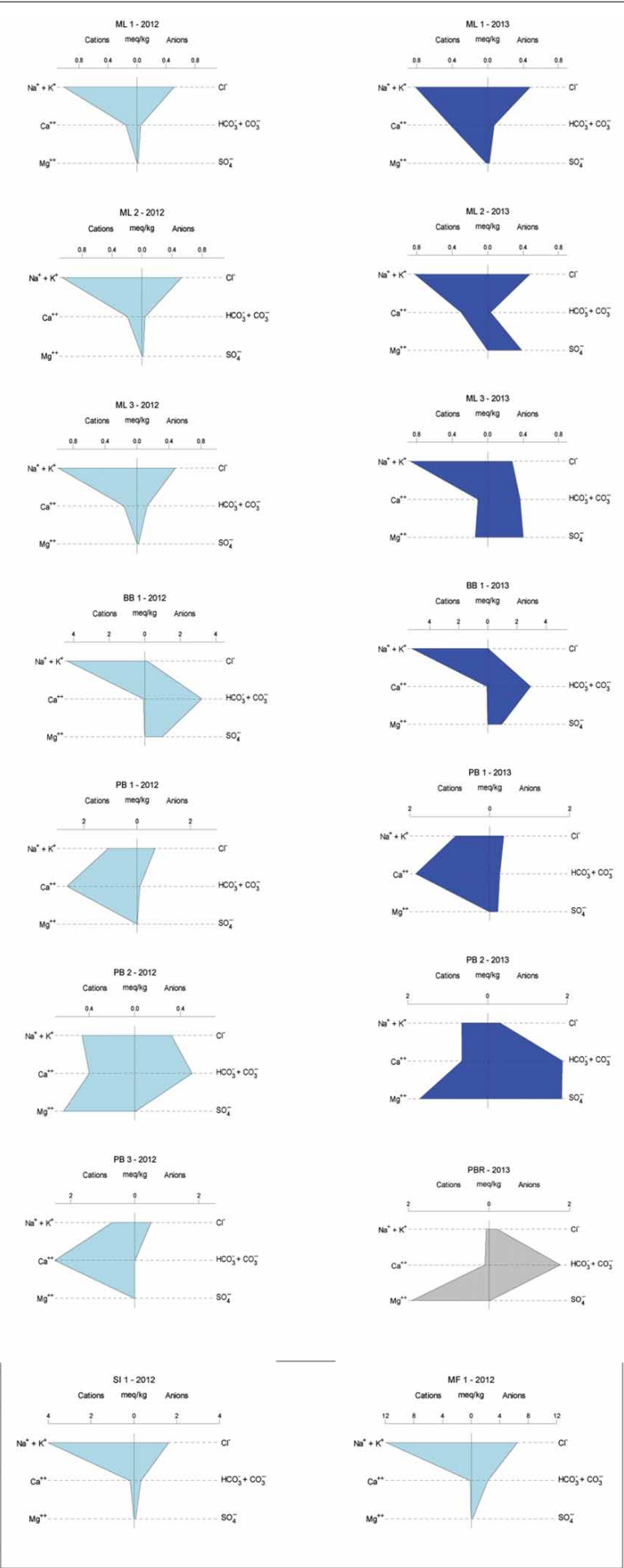

FIGURE 4 | Geochemical variability across years in the sample set, given as Stiff diagrams, for which similar shapes connote similar major ion patterns. 2012 samples are in light blue, 2013 samples are in dark blue, and sample sites correspond from left to right except for single visit locations. SI1 and MF1 sites are in Palawan and were visited once. PB3 is the most upstream in the PB series of springs and was completely destroyed by vigorous rains between sampling years. Poon Bato River data are provided for context, in gray. from Figure 6. Dissolved gases at Bigbiga (BB1) consist essentially of $\mathrm{CO}_{2}$. This spring stands aparts from the others as a $\mathrm{CO}_{2}$ effervescing spring with relatively oxidized gas phase carbon, and no detected reduced gases. It is likely open to the atmosphere at some point in its recharge path. $\mathrm{H}_{2}$ and $\mathrm{CH}_{4}$ are observed at low concentrations at site $\mathrm{PB} 2$, with the gas balance as $\mathrm{CO}_{2}$. At $\mathrm{PB} 2$, the data can be interpreted as reflecting mixing between a $\mathrm{CO}_{2}$-bearing, surface-derived, shallow groundwater regime and a separate, deeply sourced water carrying reduced gases. ML1, ML2 are nearly $50 \%-50 \%$ mixtures of $\mathrm{H}_{2}$ and $\mathrm{CH}_{4}$, with a small proportion of $\mathrm{CO}_{2}$, if present. Gas contents at ML1 and ML2 indicate that these waters provide a plausible, deeply sourced end-member composition.

\section{DISCUSSION}

\section{AQUEOUS AND GAS GEOCHEMISTRY}

Of these newly characterized sites in the Philippines Ophiolites, the Poon Bato springs PB1 and PB3 are typical $\mathrm{Ca}^{2+}-\mathrm{OH}^{-}$ type waters (c.f., Barnes et al., 1967), and can be interpreted as sourced in actively serpentinizing host rock; PB2 has relatively higher $\mathrm{Mg}^{2+}$ content, indicative of some mixing with open system $\mathrm{Mg}^{2+}-\mathrm{HCO}_{3}^{-}$waters. The Manleluag springs ML1-ML3 express a muted serpentinization signal in the aqueous geochemistry, with less $\mathrm{Ca}^{2+}$ and lower $\mathrm{pH}$. Given that all country rock observed in the Manleluag area was gabbroic (deep ocean crustal rocks rather than peridotitic mantle units), waters may be escaping along a subsurface mafic-ultramafic contact (i.e., the interface between the gabbros and altering peridotites, or the interface between the crust and the mantle rocks). The gas data for $\mathrm{PB}$ and ML sites support this interpretation, indicating incorporation of $\mathrm{H}_{2}$ and $\mathrm{CH}_{4}$ likely derived from regional serpentinization.

BB1 well water samples, known to be sourced in altered pillow basalts may have some hydrological communication with extensive, adjacent bentonite clay sedimentary deposits. These waters have a lower $\mathrm{pH}$ signal, higher salinity, and are the only waters in which sulfate was detected in both sampling years, perhaps due to perennial leakage from sedimentary formations. Note the changing scale in Figure 4, with increasing salinity for BB1; SI1 and MF1 waters also have enhanced salinity, dramatically so for MF1, with range up to $12 \mathrm{meq} / \mathrm{kg}$ in Figure 4, along with relatively reducing oxidation-reduction potential. The relatively high salinity coupled with the weak Ca signal suggests that these waters (MF1, SI1) are groundwaters isolated from serpentinization reactions in the subsurface.

Variation in DIC and DOC between sites and at the same sites in different years is unpredictable (Table 2). These field locations are some of the first described in tropical climates, and are likely heavily influenced not only by seasonal variations in precipitation, but also vegetative input to the springs. As some site locations were sampled in different years, and under different climate conditions, these unpredictable variations can be observed (Table 4). DIC is typically low in sites with corresponding low ORP, and high in locations that have more opportunity to equilibrate with atmospheric $\mathrm{CO}_{2}$ (e.g., BB1, PBR, MF1). Comparing 2012 vs. 2013 values, which represent dryer vs. wetter climate conditions, respectively, concentrations of DIC increase at some sites and decrease at others. 


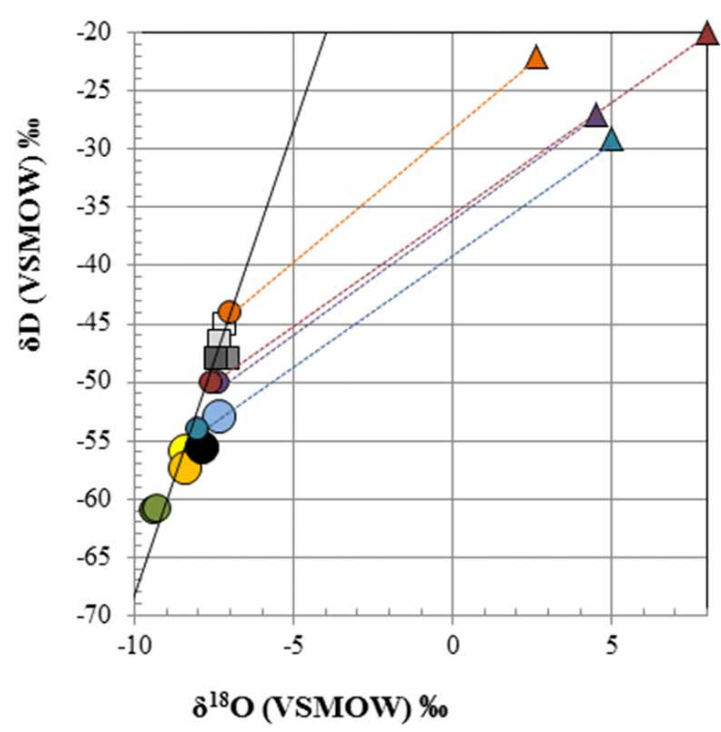

- Poon Bato 1

- Poon Bato 2

- Manleluag 1

- Manleluag 2

- Quezon Citymeteoric

PHL MNL

- Bigbiga artesian well

口 SNGF shallow groundwater

$\square$ SNGF deep groundwater

口 SNGF warm springs

- SNGF cold springs

- Alto Peak meteoric

$\Delta$ Alto Peak, most shifted andesitic water

- Cagua meteoric water

$\Delta$ Cagua, most shifted andesitic water

- Mahagnao, meteoric water

$\Delta$ Mahagnao, most shifted andesitic water

- Mt. Pinatubo, meteoric water

$\Delta$ Mt. Pinatubo, most shifted andesitic water

- Linear (PHL MWL)

FIGURE 5 | Stable isotope data for spring waters presented with the current meteoric water line for the Philippines and a suite of meteoric and andesitic waters from the region; the latter are color-coded to show that the source water (circles) are driven to the upper right via interaction with andesitic volcanism (along dashed lines) to the cluster of magmatically associated waters (triangles). Note that all of the spring data for this study cluster near/on the MWL for the region, without a significant magmatic water component.
Table 3 | Dissolved gas concentrations, obtained via gas-stripping of gas-rich aqueous samples.

\begin{tabular}{|c|c|c|c|c|c|}
\hline Locality & Site & $\mathrm{H}_{2}(\mu \mathrm{M})$ & $\mathrm{CO}(\mu \mathrm{M})$ & $\mathrm{CH}_{4}(\mu \mathrm{M})$ & $\mathrm{CO}_{2}(\mu \mathrm{M})$ \\
\hline \multirow[t]{8}{*}{ Zambales, 2012} & ML1 & 207.0 & 0.1 & 187.2 & 0.0 \\
\hline & ML2 & 239.1 & 0.0 & 186.8 & 1.6 \\
\hline & ML3 & 0.0 & 0.0 & 0.0 & 0.0 \\
\hline & BB1 & 0.0 & 0.1 & 1.2 & 2568.2 \\
\hline & PB1 & 0.0 & 0.0 & 0.0 & 0.0 \\
\hline & PB2 & 7.2 & 0.2 & 33.5 & 359.4 \\
\hline & PB3 & 0.0 & 0.0 & 0.0 & 0.0 \\
\hline & PBR & 0.0 & 0.0 & 0.0 & 0.0 \\
\hline \multirow[t]{2}{*}{ Palawan, 2012} & SI1 & 0.0 & 0.1 & 631.6 & 57.5 \\
\hline & MF1 & - & - & - & - \\
\hline \multirow[t]{7}{*}{ Zambales, 2013} & ML1 & 473.9 & 0.0 & 372.8 & 23.9 \\
\hline & ML2 & 495.5 & 0.0 & 400.0 & 6.8 \\
\hline & ML3 & 85.4 & 0.0 & 119.8 & 120.2 \\
\hline & BB1 & 0.0 & 0.0 & 0.0 & 2496.4 \\
\hline & PB1 & 161.2 & 0.0 & BDL & BDL \\
\hline & PB2 & 0.0 & 0.0 & BDL & 1755.3 \\
\hline & PBR & - & 0.0 & - & - \\
\hline
\end{tabular}

Presumably, the underlying hydrology in combination with surface influences cause these variations. The isotopic composition of DIC in these fluids ranges from $\sim-11$ to $-25 \%$. Values that approach $\sim-7 \%$ likely indicate interactions with atmospheric $\mathrm{CO}_{2}$, in other words, an open system with respect to $\mathrm{CO}_{2}$, while more depleted values may reflect microbial waste product build up in springs that are somewhat isolated from surface processes. In comparison to other terrestrial serpentinizing seeps (few, where data are available), DIC at most Philippines sites have enriched isotopic compositions. For example, The Cedars (CA, USA) and Tablelands (Canada) locations host fluids with DIC that show isotopic compositions between $\sim-30$ to $-32 \%$ (Morrill et al., 2013; Szponar et al., 2013). Again, DIC that is isotopically enriched may indicate mixing with fluids that are more associated with surface processes. Regardless, low DIC concentrations in the Philippines systems mean that subsurface microbial ecosystems (1) may be carbon poor, and (2) any microbial fractionation during carbon fixation will be starting from carbon that is less enriched in ${ }^{13} \mathrm{C}$ than surface fluids. This latter will have implications for any additional studies of carbon isotope compositions of biomass.

DOC concentrations are similarly unpredictable, between sample locations and sample years. The degree of additional organic carbon input from the surrounding heavily vegetated surface environment is a variable that cannot be controlled. Thus, DOC may play a large role in microbial metabolic function in these particular springs that other terrestrial serpentinizing springs lack (such as those in more arid climates, for example), even though the overall concentration of DOC in these systems appears to be relatively low. It might be expected that DOC concentrations would increase with increased precipitation. However, with only a few exceptions, this is not the case in the Philippines field sites. In contrast, increased precipitation may have diluted the DOC, or contributed to otherwise flushing vegetative build up from the pools. Isotopic composition of the DOC is, predictably, depleted relative to that of DIC at all sites except for the 2012 PB1 sample. DOC in other terrestrial serpentinizing 


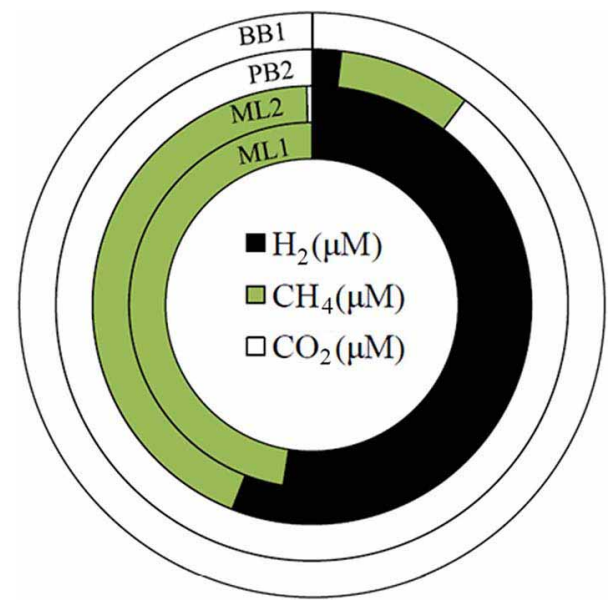

FIGURE 6 | Dissolved gas findings (reported in Table 3) shown as side-by-side gas doughnut diagrams. Note that the sampled sites range from $\mathrm{H}_{2}$ - and $\mathrm{CH}_{4}$-dominated (ML1 and $\mathrm{ML2}$, inner green and black doughnuts) to nearly completely $\mathrm{CO}_{2}$-dominated (BB1, white doughnut).

systems has also been reported to be low ( $<2$ ppm-Morrill et al., 2013; Szponar et al., 2013). However, the Philippines systems may have benefit of a more consistently supplied influx of surface derived DOC, due to the dense vegetation and frequent flushing (and refreshing) of the system during precipitation events. DOC isotopic compositions at these sites are more depleted in comparison with DOC reported from the Tablelands and the Cedars locations (Morrill et al., 2013; Szponar et al., 2013)—this may indicate less recycling of carbon in the system compared to other terrestrial sites. Further, heterotrophic metabolism in the subsurface should produce isotopically heavier $\mathrm{CO}_{2}$ as a waste product, which would be added to any native DIC.

\section{GEOCHEMICAL MODELING OF METABOLIC REACTIONS}

We modeled the activities of chemical species important for microbial metabolisms based on geochemical data for 9 ophiolite-associated groundwaters (several sampled in both field seasons) and 1 regional river water, to determine if selected metabolic reactions are supported in these aqueous environments. Metabolisms (reactions provided in caption to Figure 7) were chosen to mirror those chemosynthetic metabolic strategies known to be utilized at sites of active serpentinization (such as those profiled in Table 1). For reference, Schrenk et al. (2013) group continental and marine serpentinites conceptually as a biome, detailing that low cell counts and a relatively low diversity of microbial types have been documented in a number of field studies in serpentinites. In the Archaea, representatives of the Crenarchaeota (Desulfurococcales) and Euryarchaeota, (Archaeoglobales, Thermococcales, Methanococcales, Methanobacteriales, Methanopyrales, Methanosarcinales, ANME-2, and ANME1 groups) have been detected. In the Bacteria, representatives of the Aquificae, Bacteroidetes, Betaproteobacteria (including Hydrogenophaga), Gammaproteobacteria, Deltaproteobacteria, Epsilonproteobacteria, Thermodesulfobacteria, Actinobacteria,
Table 4 | New data for the stable isotopes of water in springs of the Zambales and Palawan Ophiolites, presented with additional regional data, related to the establishment of a local meteoric water line (Gerardo-Abaya, 2005) and documentation of springs with isotopic characteristics signaling interaction with country rock and magmatic processes (Giggenbach, 1992).

$\begin{array}{ccc}\text { Site } & \delta^{18} \mathrm{O} & \delta \mathrm{D} \\ \text { (SMOW) } & \text { (SMOW) }\end{array}$

\section{Zambales, PB1}

Zambales, PB2

Zambales, ML1

Zambales, ML2

Zambales, BB1

Palawan, SI1

Palawan, MF1

Quezon City, NIGS, meteoric

water

Southern Negros Geothermal

Field, shallow groundwater

Southern Negros Geothermal

Field, deep groundwater

Southern Negros Geothermal

Field, warm springs

Southern Negros Geothermal

Field, cold springs

Alto Peak, meteoric water

Alto Peak, most shifted

andesitic water

Cagua, meteoric water

Cagua, most shifted andesitic water

Mahagnao, meteoric water

Mahagnao, most shifted

andesitic water

Mt. Pinatubo, meteoric water

Mt. Pinatubo, most shifted

andesitic water

$\begin{array}{lll}-8.4 & -55.8 & \text { This study } \\ -8.5 & -57.2 & \text { This study } \\ -9.4 & -60.9 & \text { This study } \\ -9.3 & -60.7 & \text { This study } \\ -7.9 & -55.5 & \text { This study } \\ -7.5 & -45.6 & \text { This study } \\ -6.9 & -43.6 & \text { This study } \\ -7.4 & -52.8 & \text { This study }\end{array}$

$-7.2 \quad-45.0 \quad$ Gerardo-Abaya, 2005

$-7.4 \quad-46.5 \quad$ Gerardo-Abaya, 2005

$-7.1 \quad-48.0 \quad$ Gerardo-Abaya, 2005

$-7.5 \quad-48.0 \quad$ Gerardo-Abaya 2005

$\begin{array}{lll}-7 & -44 & \text { Giggenbach, } 1992\end{array}$ $2.6 \quad-22 \quad$ Giggenbach, 1992

$-7.5 \quad-50 \quad$ Giggenbach, 1992 $4.5 \quad-27 \quad$ Giggenbach, 1992

$-7.5 \quad-50 \quad$ Giggenbach, 1992 $8 \quad-20 \quad$ Giggenbach, 1992 $5 \quad-29 \quad$ Giggenbach, 1992 $\begin{array}{lll}-8 & -54 & \text { Giggenbach, } 1992\end{array}$

and Firmicutes have been observed (Schrenk et al., 2013). Accordingly, metabolisms that are tied to methane cycling and hydrogen oxidation are considered here, as well as other reactions that make use of ferric iron, sulfur, and/or N-compounds in the ultramafic environment.

Hydrogen oxidation via the knallgas reaction has the greatest bioenergetic yield in the modeled system. In general, given the nature of this study, environmental samples were collected at the interface between a relatively reducing aqueous system (groundwaters linked to serpentinization in most cases) and a relatively oxidizing system (open to the atmosphere). Although energy yields are not as great for sulfate reduction coupled to hydrogen oxidation, where sulfate is of meaningful concentration (BB1, ML sites, MF1, SI1), this metabolism is also feasible.

Several aspects of methane cycling were treated in this model. Because spring waters and well samples were all collected at the interface between surface and subsurface biogeochemical 


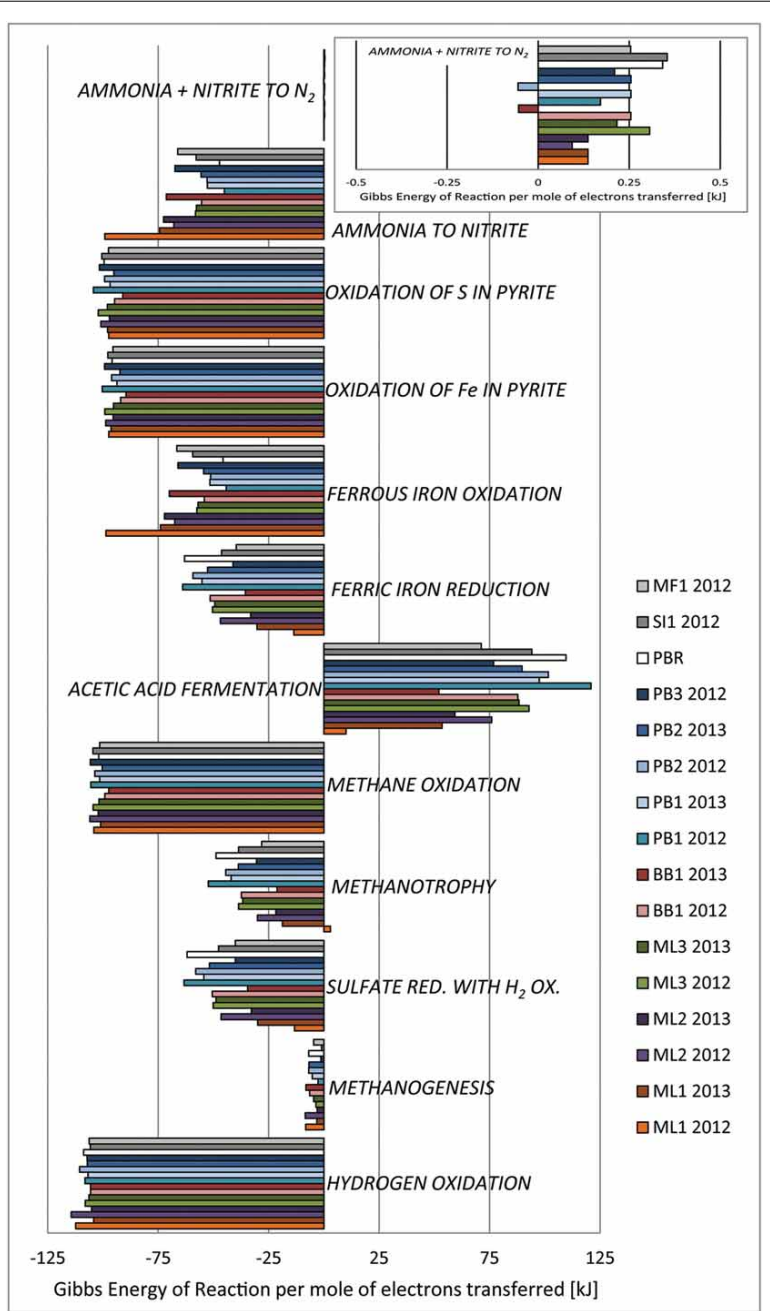

FIGURE 7 | Microbiological metabolic strategies, pitched as chemical reactions, are evaluated for Gibbs energy yield as in Amend and Shock (2001), based on modeled activities derived from environmental data. Recall that spontaneous reactions have $\Delta G_{r}<0$. The geochemical environments considered here cause shifts in the thermodynamic feasibility of reactions. TDS were estimated from field conductivity data.

Hydrogen oxidation: $\mathrm{H}_{2 \text { (aq) }}+0.5 \mathrm{O}_{2 \text { (aq) }}=\mathrm{H}_{2} \mathrm{O}_{(l)}$

Methanogenesis: $\mathrm{CO}_{2 \text { (aq) }}+4 \mathrm{H}_{2 \text { (aq) }}=\mathrm{CH}_{4(\text { aq })}+2 \mathrm{H}_{2} \mathrm{O}_{(l)}$

Sulfate reduction coupled to hydrogen oxidation: $\mathrm{SO}_{4}^{2-}+4 \mathrm{H}_{2(\text { aq) }}+2 \mathrm{H}^{+}=$

$\mathrm{H}_{2} \mathrm{~S}_{(\text {aq) }}+4 \mathrm{H}_{2} \mathrm{O}_{(!)}$

Methanotrophy: $\mathrm{CH}_{4(\mathrm{aq})}+\mathrm{SO}_{4}^{2-}+2 \mathrm{H}^{+}=\mathrm{HCO}_{3}^{-}+\mathrm{H}_{2} \mathrm{~S}_{(\text {aq })}+\mathrm{H}_{2} \mathrm{O}_{(l)}$

Methane oxidation: $\mathrm{CH}_{4(\text { aq })}+2 \mathrm{O}_{2 \text { (aq) }}=\mathrm{CO}_{2 \text { (aq) }}+2 \mathrm{H}_{2} \mathrm{O}_{(\text {(l) }}$

Acetic acid disproportionation: acetic acid(aq) $=\mathrm{CH}_{4(\mathrm{aq})}+\mathrm{CO}_{2 \text { (aq) }}$

Ferric iron reduction: $\mathrm{H}_{2 \text { (aq) }}+2 \mathrm{Fe}^{3+}=2 \mathrm{Fe}^{2+}+2 \mathrm{H}^{+}$

Ferrous iron oxidation: $2 \mathrm{Fe}^{2+}+0.5 \mathrm{O}_{2(\mathrm{aq})}+2 \mathrm{H}^{+}=2 \mathrm{Fe}^{3+}+\mathrm{H}_{2} \mathrm{O}_{(\|)}$

Oxidation of $\mathrm{Fe}$ in pyrite: 2 pyrite(s) $+7.5 \mathrm{O}_{2 \text { (aq) }}+\mathrm{H}_{2} \mathrm{O}_{(\|)}=2 \mathrm{Fe}^{3+}+$

$4 \mathrm{SO}_{4}^{2-}+2 \mathrm{H}^{+}$

Oxidation of $\mathrm{S}$ in pyrite: pyrite $+3.5 \mathrm{O}_{2 \text { (aq) }}+\mathrm{H}_{2} \mathrm{O}_{(\|)}=\mathrm{Fe}^{2+}+2 \mathrm{SO}_{4}^{2-}+2 \mathrm{H}^{+}$

Nitrification: $\mathrm{NH}_{3}+1.5 \mathrm{O}_{2 \text { (aq) }}=\mathrm{H}^{+}+\mathrm{NO}_{2}^{-}+\mathrm{H}_{2} \mathrm{O}_{())}$

Ammonia oxidation: $\mathrm{NH}_{3(\text { aq })}+\mathrm{NO}_{2}^{-}+\mathrm{H}^{+}=\mathrm{N}_{2 \text { (aq) }}+2 \mathrm{H}_{2} \mathrm{O}_{(l)}$.

systems, it is to be expected that $\mathrm{CO}_{2}$ is dissolving into the system, providing the reactants for methanogenesis, and it is to be expected that organic acids produced abiotically by serpentinization would also be present, possibly fueling acetic acid disproportionation. Both of these metabolisms were evaluated in the model. Methanogenesis is feasible but with the lowest calculated energy yield. Acetic acid fermentation is not feasible, likely due to the environmental abundance of methane and very low expected concentrations of acetate. Methane is abiotically produced in serpentinization, and so would be a common reactant for metabolism: both methane oxidation and methanotrophy coupled with sulfate reduction are feasible based on the model results.

Given the possible mixing of Type I and II waters in these subsurface hydrological flow regimes, there may be aqueous ferrous iron inputs tied to the surface-related water; at the same time, the mineral-hosted iron in serpentinized ultramafics is likely to be ferric, with some ferrous iron locked in nearly insoluble oxides and oxyhydroxides. In the absence of thermodynamic data at elevated temperatures for many solid phases of interest in microbial iron cycling (such as the minerals goethite and ferrihydrite), we relied on the aqueous phase Fe redox transformations, coupled with $\mathrm{H}_{2}$ oxidation: both iron oxidation and reduction are feasible under the modeled environmental conditions.

Pyrite biodegradation, through the oxidation of either iron or sulfur, is feasible under the modeled conditions also, with relatively high energy yields. Indeed, serpentinization has been considered an important sulfur sink in the seabed (Alt and Shanks, 1998) and pyrite may be pervasive in the subsurface at ML and PB sites. In the case of BB1, we sampled an artesian well plumbing groundwaters interacting with altered pillow basalts and clayrich sedimentary formations. The adjacent sedimentary unit is composed primarily of smectite-group clays and zeolites (x-ray diffraction data are not shown, but confirm mineral identifications), and pyrite is a reasonable minor component in this system, as a common diagenetic mineral.

Nitrification and ammonia oxidation reactions were also assessed for bioenergetics yield. Nitrification was thermodynamically favored in the modeled environments, while ammonia oxidation was not. Ammonia oxidation, as written here (Figure 7 caption) requires protons as a reactant, and in the high $\mathrm{pH}$ environments, the dearth of protons likely impedes this reaction. In fact, the energy yields are near zero for all sites considered. However, the inset box in Figure 7 shows the ammonia oxidation results hover near $\Delta G_{\mathrm{r}}=0$; note that the Gibbs energy values for this metabolic strategy are slightly negative (thus the metabolism is favored) only for sites BB1 and PB2 in 2013. The swing from $\Delta G_{r}>0$ to $\Delta G_{r}<0$ between sampling years indicates that the metabolic strategy may be feasible under some field conditions, and does in fact shift from environmentally supported to environmentally inhibited over time, as is shown by our year-to-year shift.

In sum, calculated Gibbs energy of reaction values (calculated at environmental conditions) at all sites indicate that most selected metabolisms are indeed feasible, with Gibbs energy $<0$, indicating a thermodynamic potential for the reaction to proceed to the right, as written, under the specified conditions (Figure 7). Two exceptions occur: acetic acid disproportionation [i.e., acetic $\operatorname{acid}_{(\mathrm{aq})}=\mathrm{CH}_{4(a q)}+\mathrm{CO}_{2(\mathrm{aq})}$ [ and ammonia oxidation in the presence of nitrite [i.e., $\mathrm{NH}_{3(\mathrm{aq})}+\mathrm{NO}_{2}^{-}+\mathrm{H}^{+}=$ $\mathrm{N}_{2(\mathrm{aq})}+2 \mathrm{H}_{2} \mathrm{O}_{(\mathrm{l})}$ ] are not shown to be feasible in the geochemical 
environment. No site supports acetic acid disproportionation (taken as a proxy for fermentation of acetate).

Interestingly, working with environmental samples collected at ML sites in tandem with those used for geochemical analysis and thus linked directly to the model results, Woycheese et al. (2015) report several putative metabolisms (based on nearest neighbor taxonomic affiliations via $16 \mathrm{~S}$ rRNA gene amplicon sequencing on the Illumina MiSeq platform) that resonate with the geochemical modeling presented here.

Hydrogen oxidation is likely a major metabolism in the ML series springs: $16 \mathrm{~S}$ data show that there are two hydrogenoxidizing genera in the environment. Hydrogenophaga comprised $1.3 \%$ of sequence reads at the upstream edge of site ML2, $7.1 \%$ of reads at the downstream edge of ML2, and 3.4\% of reads at ML3. Thiobacillus (family Hydrogenophilace) accounted for 0.02, 4.4 , and $9.2 \%$ of sequence reads, at ML1-ML3, respectively.

$16 \mathrm{~S}$ data also inform the case for methane cycling in these ophiolite-associated springs. Methanogenesis is likely one of the dominant metabolisms at ML1: the archaeal family Methanobacteriaceae makes up about $7 \%$ of sequence reads at the upstream edge of site ML2, and 3.4\% of reads at the downstream edge of ML2. At ML3, percentages are much lower $(0.06 \%$ of reads); suggesting communities shift as the physicalchemical conditions evolve in the running stream water. We noted the methanotrophic bacterial genera Methylobacteriaceae, Methylocystaceae, and Methylobacillus in the rare taxa, comprising less than $0.03 \%$ of sequence reads. Acetic acid fermentation is not prominent in the $16 \mathrm{~S}$ data, but there are traces of the family Acetobacteraceae at the upstream edge of site ML2 $(0.01 \%$ sequence abundance), downstream edge of site ML2 ( $0.4 \%$ sequence abundance), and ML3 ( $1.2 \%$ sequence abundance). $16 \mathrm{~S}$ data do not speak to sulfur cycling, and have very little evidence for iron cycling in the ML sites. Here, less than $0.2 \%$ of sequence reads aligned with the iron-oxidizing bacterial family Thermodesulfovibrionaceae. Lastly, ammonia-related sequence reads are not significant; the archaeal genus Candidatus Nitrososphaera comprised less than $0.099 \%$ of sequence reads for ML sites.

\section{CONCLUDING REMARKS}

In this work, we construct one possible model for the metabolic niches available to microbes in several ophiolite-associated springs in the Zambales and Palawan Ophiolites, Philippines. We provide field descriptions, new aqueous environmental data, and an analysis of the feasibility of several microbial metabolisms that are prominent in deep subsurface habitats. We find that several springs (ML series and PB series) exhibit geochemical patterns indicative of active serpentinization in the ultramafic subsurface, while waters sampled at BB1, SI1, and MF1 appear to be mixtures of meteoric and other waters derived from the alteration of other units in the oceanic crust, now tectonically emplaced on land. The composite metabolic framework observed in these ophiolitehosted springs, presented graphically here (Figure 7), aligns some hydrogen-oxidizing, methane cycling, Fe- and S-utilizing, and nitrogen cycling reactions, illustrating metabolisms available to subsurface microbes. This work defines a metabolic space or "landscape" based on system geochemistry, and provides a framework in which to conduct analyses of active metabolic strategies in this geologically unique environment.

\section{ACKNOWLEDGMENTS}

This research was made possible by grant funds from the National Science Foundation's Geobiology and Low Temperature Geochemistry Program via Collaborative Research Awards 1146910 to Dawn Cardace and 1147334 to D'Arcy R. MeyerDombard. We are grateful to K. Wilkinson, T. J. Scott of University of Rhode Island-Geosciences, T. Hoehler, D. Carnevale, M. Kubo of NASA Ames Research Center, J. Orchardo at the Brown University Environmental Chemistry Facility, and E. Shock, N. Zolotova, K. Fecteau, K. Robinson, and R. Debes at Arizona State University for analytical support. We acknowledge that ICP-MS data were acquired through use of the RI-INBRE Centralized Research Core Facility supported by an Institutional Development Award (IDeA) from the National Institute of General Medical Sciences/NIH grant number 8 P20 GM103430. This work was supported by the USDA National Institute of Food and Agriculture, Hatch funding and the Rhode Island Agricultural Experiment Station, contribution \#5418.

\section{SUPPLEMENTARY MATERIAL}

The Supplementary Material for this article can be found online at: http://www.frontiersin.org/journal/10.3389/fmicb. 2015.00010/abstract

\section{REFERENCES}

Abrajano, T. A., Sturchio, N. C., Bohlke, J. K., Lyon, G. L., Poreda, R. J., and Stevens, C. M. (1988). Methane hydrogen gas seeps, zambales ophiolite, philippines-deep or shallow origin. Chem. Geol. 71, 211-222. doi: 10.1016/0009-2541(88)90116-7

Alt, J. C., and Shanks, W. C. (1998). Sulfur in serpentinized oceanic peridotites: serpentinization processes and microbial sulfate reduction. J. Geophys. Res. Solid Earth (1978-2012) 103.B5, 9917-9929.

Amend, J. P., McCollom, T. M., Hentscher, M., and Bach, W. (2011). Catabolic and anabolic energy for chemolithoautotrophs in deep-sea hydrothermal systems hosted in different rock types. Geochim. Cosmochim. Acta 75, 5736-5748. doi: 10.1016/j.gca.2011.07.041

Amend, J. P., and Shock, E. L. (2001). Energetics of overall metabolic reactions of thermophilic and hyperthermophilic Archaea and Bacteria. FEMS Microbiol. Rev. 25, 175-243. doi: 10.1111/j.1574-6976.2001.tb00576.x

Aurelio, M. A., and Pena, R. E. (eds.). (2010). Geology of the Philippines. Quezon City: Mines and Geosciences Bureau.

Bach, W., Garrido, C. J., Paulick, H., Harvey, J., and Rosner, M. (2004). Seawater-peridotite interactions: first insights from ODP Leg 209, MAR 15 degrees N. Geochem. Geophys. Geosyst. 5, Q09F26. doi: 10.1029/2004GC 000744

Barnes, I., Lamarche, V. C., and Himmelbe, G. (1967). Geochemical evidence of present-day serpentinization. Science 156, 830-832. doi: 10.1126/science.156.3776.830

Barnes, I., Oneil, J. R., and Trescases, J. J. (1978). Present day serpentinization in New-Caledonia, Oman and Yugoslavia. Geochim. Cosmochim. Acta 42, 144-145. doi: 10.1016/0016-7037(78)90225-9

Barnes, I., Sheppard, R. A., Gude, A. J., Rapp, J. B., and Oneil, J. R. (1972). Metamorphic assemblages and direction of flow of metamorphic fluids in 4 instances of serpentinization. Contribut. Mineral. Petrol. 35, 263. doi: 10.1007/BF00371220

Blank, J. G., Green, S., Blake, D., Valley, J. W., Kita, N. T., Treiman, A., et al. (2009). An alkaline spring system within the Del Puerto Ophiolite (California, USA): a Mars analog site. Planet. Space Sci. 57, 533-540. doi: 10.1016/j.pss.2008. 11.018 
Boschetti, T., and Toscani, L. (2008). Springs and streams of the Taro-Ceno Valleys (Northern Apennine, Italy): reaction path modeling of waters interacting with serpentinized ultramafic rocks. Chem. Geol. 257, 76-91. doi: 10.1016/j.chemgeo.2008.08.017

Boulart, C., Chavagnac, V., Monnin, C., Delacour, A., Ceuleneer, G., and Hoareau, G. (2013). Differences in gas venting from ultramafic-hosted warm springs: the example of oman and voltri ophiolites. Ofioliti 38, 143-156. doi: 10.4454/ofioliti.v38i2.423

Brazelton, W. J., Mehta, M. P., Kelley, D. S., and Baross, J. A. (2011). Physiological differentiation within a single-species biofilm fueled by serpentinization. mBio 2, e00127-00111. doi: 10.1128/mBio.00127-11

Brazelton, W. J., Morrill, P. L., Szponar, N., and Schrenk, M. O. (2013). Bacterial communities associated with subsurface geochemical processes in continental serpentinite springs. Appl. Environ. Microbiol. 79, 3906-3916. doi: 10.1128/AEM.00330-13

Brazelton, W. J., Schrenk, M. O., Kelley, D. S., and Baross, J. A. (2006). Methane- and sulfur-metabolizing microbial communities dominate the Lost City hydrothermal field ecosystem. Appl. Environ. Microbiol. 72, 6257-6270. doi: 10.1128/AEM.00574-06

Bruni, J., Canepa, M., Chiodini, G., Cioni, R., Cipolli, F., Longinelli, A., et al. (2002). Irreversible water-rock mass transfer accompanying the generation of the neutral, $\mathrm{Mg}-\mathrm{HCO} 3$ and high-pH, $\mathrm{Ca}-\mathrm{OH}$ spring waters of the Genova province, Italy. Appl. Geochem. 17, 455-474. doi: 10.1016/S0883-2927(01)00113-5

Cardace, D., Hoehler, T., McCollom, T., Schrenk, M., Carnevale, D., Kubo, M., et al. (2013). Establishment of the Coast Range ophiolite microbial observatory (CROMO): drilling objectives and preliminary outcomes. Sci. Drill. 16, 45-55. doi: $10.5194 /$ sd-16-45-2013

Cardace, D., and Hoehler, T. M. (2009). Serpentinizing fluids craft microbial habitat. Northeast. Nat. 16, 272-284. doi: 10.1656/045.016.0520

Chapelle, F. H., O’Neill, K., Bradley, P. M., Methe, B. A., Ciufo, S. A., Knobel, L. L., et al. (2002). A hydrogen-based subsurface microbial community dominated by methanogens. Nature 415, 312-315. doi: 10.1038/415312a

Charlou, J. L., Donval, J. P., Fouquet, Y., Jean-Baptiste, P., and Holm, N. (2002). Geochemistry of high $\mathrm{H}(2)$ and $\mathrm{CH}(4)$ vent fluids issuing from ultramafic rocks at the Rainbow hydrothermal field (36 degrees 14/ N, MAR). Chem. Geol. 191, 345-359. doi: 10.1016/S0009-2541(02)00134-1

Charlou, J. L., Fouquet, Y., Bougault, H., Donval, J. P., Etoubleau, J., JeanBaptiste, P., et al. (1998). Intense $\mathrm{CH}(4)$ plumes generated by serpentinization of ultramafic rocks at the intersection of the 15 degrees 20 ' N fracture zone and the Mid-Atlantic Ridge. Geochim. Cosmochim. Acta 62, 2323-2333. doi: 10.1016/S0016-7037(98)00138-0

Chassefiere, E., Langlais, B., Quesnel, Y., and Leblanc, F. (2013). The fate of early Mars' lost water: the role of serpentinization. J. Geophys. Res. Planets 118, 1123-1134. doi: 10.1002/jgre.20089

Chavagnac, V., Ceuleneer, G., Monnin, C., Lansac, B., Hoareau, G., and Boulart, C. (2013a). Mineralogical assemblages forming at hyperalkaline warm springs hosted on ultramafic rocks: a case study of Oman and Ligurian ophiolites. Geochem. Geophys. Geosyst. 14, 2474-2495. doi: 10.1002/ggge.20146

Chavagnac, V., Monnin, C., Ceuleneer, G., Boulart, C., and Hoareau, G. (2013b). Characterization of hyperalkaline fluids produced by low-temperature serpentinization of mantle peridotites in the Oman and Ligurian ophiolites. Geochem. Geophys. Geosyst. 14, 2496-2522. doi: 10.1002/ggge.20147

Cipolli, F., Gambardella, B., Marini, L., Ottonello, G., and Zuccolini, M. V. (2004). Geochemistry of high-pH waters from serpentinites of the Gruppo di Voltri (Genova, Italy) and reaction path modeling of $\mathrm{CO}_{2}$ sequestration in serpentinite aquifers. Appl. Geochem. 19, 787-802. doi: 10.1016/j.apgeochem.2003. 10.007

Daae, F. L., Okland, I., Dahle, H., Jorgensen, S. L., Thorseth, I. H., and Pedersen, R. B. (2013). Microbial life associated with low-temperature alteration of ultramafic rocks in the Leka ophiolite complex. Geobiology 11, 318-339. doi: 10.1111/gbi.12035

D’Hondt, S. (2013). Subsurface sustenance. Nat. Geosci. 6, 426-427. doi: $10.1038 /$ ngeo 1843

Dias, A. S., and Barriga, F. (2006). Mineralogy and geochemistry of hydrothermal sediments from the serpentinite-hosted Saldanha hydrothermal field (36 degrees $34^{\prime} \mathrm{N} ; 33$ degrees $26^{\prime} \mathrm{W}$ ) at MAR. Mar. Geol. 225, 157-175. doi: 10.1016/j.margeo.2005.07.013

Dias, A. S., Frueh-Green, G. L., Bernasconi, S. M., Barriga, F. J. A. S., Seahma cruise team., and Charles Darwin 167 cruise team. (2011). Geochemistry and stable isotope constraints on high-temperature activity from sediment cores of the Saldanha hydrothermal field. Mar. Geol. 279, 128-140. doi: 10.1016/j.margeo.2010.10.017

Ehlmann, B. L., Mustard, J. F., Clark, R. N., Swayze, G. A., and Murchie, S. L. (2011). Evidence for low-grade metamorphism, hydrothermal alteration, and diagenesis on mars from phyllosilicate mineral assemblages. Clays Clay Miner. 59, 359-377. doi: 10.1346/CCMN.2011.0590402

Etiope, G., and Ionescu, A. (2014). Low-temperature catalytic $\mathrm{CO}_{2}$ hydrogenation with geological qunatities of ruthenium: a possible abiotic $\mathrm{CH} 4$ source in chromitite-rich serpentinized rocks. Geofluids. doi: 10.1111/gfl.12106. [Epub ahead of print].

Etiope, G., Schoell, M., and Hosgormez, H. (2011). Abiotic methane flux from the Chimaera seep and Tekirova ophiolites (Turkey): understanding gas exhalation from low temperature serpentinization and implications for Mars. Earth Planet. Sci. Lett. 310, 96-104. doi: 10.1016/j.epsl.2011.08.001

Evans, C., and Hawkins, J. W. (1989). Compositional heterogeneities in upper mantle peridotites from the zambales range ophiolite, Luzon, Philippines. Tectonophysics 168, 23-41. doi: 10.1016/0040-1951(89)90367-3

Früh-Green, G. L., Kelley, D. S., Bernasconi, S. M., Karson, J. A., Ludwig, K. A., Butterfield, D. A., et al. (2003). 30,000 years of hydrothermal activity at the lost city vent field. Science 301, 495-498. doi: 10.1126/science.1085582

Gallant, R. M., and Von Damm, K. L. (2006). Geochemical controls on hydrothermal fluids from the Kairei and Edmond Vent Fields, $23^{\circ}-25^{\circ} \mathrm{S}$, Central Indian Ridge. Geochem. Geophys. Geosyst. 7, 1-24. doi: 10.1029/2005GC001067

Gerardo-Abaya, J. (2005). "Determination of recharge from stable isotope data to the hydrological systems in the southern negros geothermal field and its environs, Philippines," in Proceedings World Geothermal Congress (Antalya).

Giggenbach, W. F. (1992). Isotopic shifts in waters from geothermal and volcanic systems along convergent plate boundaries and their origin. Earth Planet. Sci. Lett. 113, 495-510. doi: 10.1016/0012-821X(92)90127-H

Giggenbach, W. F., and Poreda, R. J. (1993). Helium isotopic and chemical composition of gases from volcanic-hydrothermal systems in the Philippines. Geothermics 22, 369-380. doi: 10.1016/0375-6505(93)90025-I

Gold, T. (1992). The deep, hot biosphere. Proc. Natl. Acad. Sci. U.S.A. 89, 6045-6049. doi: 10.1073/pnas.89.13.6045

Helgeson, H. C. (1969). Thermodynamics of hydrothermal systems at elevated temperatures and pressures. Am. J. Sci. 267:729. doi: 10.2475/ajs.267.7.729

Helgeson, H. C., Delany, J. M., Nesbitt, H. W., and Bird, D. K. (1978). Summary and critique of the thermodynamic properties of rock-forming minerals. Am. J. Sci. 278, 1-229.

Helgeson, H. C., Kirkham, D. H., and Flowers, G. C. (1981). Theoretical prediction of the thermodynamic behavior of aqueous-electrolytes at high-pressures and temperatures 4. Calculation of activity-coefficients, osmotic coefficients, and apparent molal and standard and relative partial molal properties to 600-degrees-C and 5 Kb. Am. J. Sci. 281, 1249-1516. doi: 10.2475/ajs.281. 10.1249

Hellevang, H., Huang, S., and Thorseth, I. H. (2011). The potential for lowtemperature abiotic hydrogen generation and a hydrogen-driven deep biosphere. Astrobiology 11, 711-724. doi: 10.1089/ast.2010.0559

Horita, J., and Berndt, M. E. (1999). Abiogenic methane formation and isotopic fractionation under hydrothermal conditions. Science 285, 1055-1057. doi: $10.1126 /$ science. 285.5430 .1055

Hosgormez, H., Etiope, G., and Yalcin, M. N. (2008). New evidence for a mixed inorganic and organic origin of the Olympic Chimaera fire (Turkey): a large onshore seepage of abiogenic gas. Geofluids 8, 263-273. doi: 10.1111/j.14688123.2008.00226.x

Jannasch, H. W., and Mottl, M. J. (1985). Geomicrobiology of deep-sea hydrothermal vents. Science 229, 717-725. doi: 10.1126/science.229.4715.717

Johnson, J. W., Oelkers, E. H., and Helgeson, H. C. (1992). Supcrt92-a software package for calculating the standard molal thermodynamic properties of minerals, gases, aqueous species, and reactions from 1-Bar to 5000Bar and 0-Degrees-C to 1000-Degrees-C. Comput. Geosci. 18, 899-947. doi: 10.1016/0098-3004(92)90029-Q

Jorgensen, B. B. (2012). Shrinking majority of the deep biosphere. Proc. Natl. Acad. Sci. U.S.A. 109, 15976-15977. doi: 10.1073/pnas.1213639109

Kallmeyer, J., Pockalny, R., Adhikari, R. R., Smith, D. C., and D'Hondt, S. (2012). Global distribution of microbial abundance and biomass in subseafloor sediment. Proc. Natl. Acad. Sci. U.S.A. 109, 16213-16216. doi: 10.1073/pnas.1203849109 
Kelley, D. S., Karson, J. A., Blackman, D. K., Fruh-Green, G. L., Butterfield, D. A., Lilley, M. D., et al. (2001). An off-axis hydrothermal vent field near the Mid-Atlantic Ridge at 30 degrees N. Nature 412, 145-149. doi: 10.1038/ 35084000

Kelley, D. S., Karson, J. A., Fruh-Green, G. L., Yoerger, D. R., Shank, T. M., Butterfield, D. A., et al. (2005). A serpentinite-hosted ecosystem: the lost city hydrothermal field. Science 307, 1428-1434. doi: 10.1126/science.1102556

Klein, F., Bach, W., Joens, N., McCollom, T., Moskowitz, B., and Berquo, T. (2009). Iron partitioning and hydrogen generation during serpentinization of abyssal peridotites from 15 degrees N on the Mid-Atlantic Ridge. Geochim. Cosmochim. Acta 73, 6868-6893. doi: 10.1016/j.gca.2009.08.021

Konn, C., Charlou, J. L., Donval, J. P., Holm, N. G., Dehairs, F., and Bouillon, S. (2009). Hydrocarbons and oxidized organic compounds in hydrothermal fluids from Rainbow and Lost City ultramafic-hosted vents. Chem. Geol. 258, 299-314. doi: 10.1016/j.chemgeo.2008.10.034

Kumagai, H., Nakamura, K., Toki, T., Morishita, T., Okino, K., Ishibashi, J. I., et al. (2008). Geological background of the Kairei and Edmond hydrothermal fields along the Central Indian Ridge: implications of their vent fluids' distinct chemistry. Geofluids 8, 239-251. doi: 10.1111/j.1468-8123.2008.00223.x

Lammer, H., Chassefiere, E., Karatekin, O., Morschhauser, A., Niles, P. B., Mousis, O., et al. (2013). Outgassing history and escape of the martian atmosphere and water inventory. Space Sci. Rev. 174, 113-154. doi: 10.1007/s11214-012-9943-8

Marques, J. M., Carreira, P. M., Carvalho, M. R., Matias, M. J., Goff, F. E., Basto, M. J., et al. (2008). Origins of high $\mathrm{pH}$ mineral waters from ultramafic rocks, Central Portugal. Appl. Geochem. 23, 3278-3289. doi: 10.1016/j.apgeochem.2008.06.029

McCollom, T. M. (2007). Geochemical constraints on sources of metabolic energy for chemolithoautotrophy in ultramafic-hosted deep-sea hydrothermal systems. Astrobiology 7, 933-950. doi: 10.1089/ast.2006.0119

McCollom, T. M., and Bach, W. (2009). Thermodynamic constraints on hydrogen generation during serpentinization of ultramafic rocks. Geochim. Cosmochim. Acta 73, 856-875. doi: 10.1016/j.gca.2008.10.032

McCollom, T. M., and Seewald, J. S. (2013). Serpentinites, hydrogen, and life. Elements 9, 129-134. doi: 10.2113/gselements.9.2.129

Meyer-Dombard, D., Woycheese, K. M., Yargicoglu, E. N., Cardace, D., Shock, E. L., Güleçal-Pektas, Y., et al. (2015). High pH microbial ecosystems in a newly discovered, ephemeral, serpentinizing fluid seep at Yanartaş (Chimaera), Turkey. Front. Microbiol. 5:723. doi: 10.3389/fmicb.2014.00723

Monnin, C. V., Chavagnac, C., Boulart, B., Ménez, M., Gérard, E., Gérard, M., et al. (2014). The low temperature hyperalkaline hydrothermal system of the Prony bay (New Caledonia). Biogeosci. Discuss. 11, 6221-6267. doi: 10.5194/bgd-116221-2014

Morrill, P. L., Kuenen, J. G., Johnson, O. J., Suzuki, S., Rietze, A., Sessions, A. L., et al. (2013). Geochemistry and geobiology of a present-day serpentinization site in California: the Cedars. Geochim. Cosmochim. Acta 109, 222-240. doi: 10.1016/j.gca.2013.01.043

Nakamura, K., Morishita, T., Bach, W., Klein, F., Hara, K., Okino, K., et al. (2009). Serpentinized troctolites exposed near the Kairei Hydrothermal Field, Central Indian Ridge: insights into the origin of the Kairei hydrothermal fluid supporting a unique microbial ecosystem. Earth Planet. Sci. Lett. 280, 128-136. doi: 10.1016/j.epsl.2009.01.024

Neal, C., and Stanger, G. (1984). Calcium and magnesium-hydroxide precipitation from alkaline groundwaters in Oman, and their significance to the process of serpentinization. Mineral. Mag. 48, 237-241. doi: 10.1180/minmag.1984.048.347.07

Neal, C., and Stanger, G. (1985). "Past and present serpentinisation of ultramafic rocks; an example from the Semail Ophiolite Nappe of Northern Oman," in The Chemistry of Weathering, ed J. I. Drever (Springer), 249-275. doi: 10.1007/97894-009-5333-8_15

Nealson, K. H., Inagaki, F., and Takai, K. (2005). Hydrogen-driven subsurface lithoautotrophic microbial ecosystems (SLiMEs): do they exist and why should we care? Trends Microbiol. 13, 405-410. doi: 10.1016/j.tim.2005.07.010

Okland, I., Huang, S., Dahle, H., Thorseth, I. H., and Pedersen, R. B. (2012). Low temperature alteration of serpentinized ultramafic rock and implications for microbial life. Chem. Geol. 318, 75-87. doi: 10.1016/j.chemgeo.2012.05.015

Orphan, V. J., and Hoehler, T. M. (2011). MICROBIOLOGY Hydrogen for dinner. Nature 476, 154-155. doi: 10.1038/476154a

Paukert, A. N., Matter, J. M., Kelemen, P. B., Shock, E. L., and Havig, J. R. (2012). Reaction path modeling of enhanced in situ $\mathrm{CO}_{2}$ mineralization for carbon sequestration in the peridotite of the Samail Ophiolite, Sultanate of Oman. Chem. Geol. 330, 86-100. doi: 10.1016/j.chemgeo.2012.08.013

Petersen, J. M., Zielinski, F. U., Pape, T., Seifert, R., Moraru, C., Amann, R., et al. (2011). Hydrogen is an energy source for hydrothermal vent symbioses. Nature 476, 176-180. doi: 10.1038/nature 10325

Prichard, H. M. (1979). Petrographic study of the process of serpentinization in ophiolites and the ocean crust. Contrib. Mineral. Petrol. 68, 231-241. doi: 10.1007/BF00371544

Proskurowski, G., Lilley, M. D., Seewald, J. S., Früh-Green, G. L., Olson, E. J., Lupton, J. E., et al. (2008). Abiogenic hydrocarbon production at Lost City hydrothermal field. Science 319, 604-607. doi: 10.1126/science.1151194

Russell, M. J., Hall, A. J., and Martin, W. (2010). Serpentinization as a source of energy at the origin of life. Geobiology 8, 355-371. doi: 10.1111/j.14724669.2010.00249.x

Russell, M. J., Nitschke, W., and Branscomb, E. (2013). The inevitable journey to being. Philos. Trans. R. Soc. B Biol. Sci. 368, 20120254-20120254. doi: 10.1098/rstb.2012.0254

Ryan, W. B. F., Carbotte, S. M., Coplan, J. O., O’Hara, S., Melkonian, A., Arko, R., et al. (2009). Global multi-resolution topography synthesis, geochem. Geophys. Geosyst. 10, Q03014. doi: 10.1029/2008GC002332

Sanchez-Murillo, R., Gazel, E., Schwarzenbach, E. M., Crespo-Medina, M., Schrenk, M. O., Boll, J., et al. (2014). Geochemical evidence for active tropical serpentinization in the Santa Elena Ophiolite, Costa Rica: an analog of a humid early Earth? Geochem. Geophys. Geosyst. 15, 1783-1800. doi: 10.1002/2013GC005213

Schmidt, K., Koschinsky, A., Garbe-Schoenberg, D., De Carvalho, L. M., and Seifert, R. (2007). Geochemistry of hydrothermal fluids from the ultramafichosted Logatchev hydrothermal field, 15 degrees $\mathrm{N}$ on the Mid-Atlantic Ridge: temporal and spatial investigation. Chem. Geol. 242, 1-21. doi: 10.1016/j.chemgeo.2007.01.023

Schrenk, M. O., Brazelton, W. J., and Lang, S. Q. (2013). Serpentinization, carbon, and deep life. Rev. Mineral. Geochem. 75, 575-606. doi: 10.2138/rmg.2013.75.18

Schrenk, M. O., Kelley, D. S., Bolton, S. A., and Baross, J. A. (2004). Low archaeal diversity linked to subseafloor geochemical processes at the Lost City Hydrothermal Field, Mid-Atlantic Ridge. Environ. Microbiol. 6, 1086-1095. doi: 10.1111/j.1462-2920.2004.00650.x

Schulte, M., Blake, D., Hoehler, T., and McCollom, T. (2006). Serpentinization and its implications for life on the early Earth and Mars. Astrobiology 6, 364-376. doi: 10.1089/ast.2006.6.364

Seewald, J. S., Zolotov, M. Y., and McCollom, T. (2006). Experimental investigation of single carbon compounds under hydrothermal conditions. Geochim. Cosmochim. Acta 70, 446-460. doi: 10.1016/j.gca.2005. 09.002

Shock, E. L., and Helgeson, H. C. (1988). Calculation of the thermodynamic and transport-properties of aqueous species at high-pressures and temperaturescorrelation algorithms for ionic species and equation of state predictions to 5-Kb and 1000-degrees-C. Geochim. Cosmochim. Acta 52, 2009-2036. doi: 10.1016/0016-7037(88)90181-0

Shock, E. L., and Helgeson, H. C. (1990). calculation of the thermodynamic and transport-properties of aqueous species at high-pressures and temperaturesstandard partial molal properties of organic-species. Geochim. Cosmochim. Acta 54, 915-945. doi: 10.1016/0016-7037(90)90429-O

Shock, E. L., Helgeson, H. C., and Sverjensky, D. A. (1989). Calculation of the thermodynamic and transport-properties of aqueous species at high-pressures and temperatures - standard partial molal properties of inorganic neutral species. Geochim. Cosmochim. Acta 53, 2157-2183. doi: 10.1016/0016-7037(89) 90341-4

Shock, E. L., Oelkers, E. H., Johnson, J. W., Sverjensky, D. A., and Helgeson, H. C. (1992). Calculation of the thermodynamic properties of aqueous species at high-pressures and temperatures - effective electrostatic radii, dissociation-constants and standard partial molal properties to 1000-degrees-C and 5-Kbar. J. Chem. Soc. Faraday Trans. 88, 803-826. doi: $10.1039 / \mathrm{ft} 9928800803$

Sleep, N. H., Meibom, A., Fridriksson, T., Coleman, R. G., and Bird, D. K. (2004). H-2-rich fluids from serpentinization: geochemical and biotic implications. Proc. Natl. Acad. Sci. U.S.A. 101, 12818-12823. doi: 10.1073/pnas.0405 289101

Suzuki, S., Ishii, S. I., Wu, A., Cheung, A., Tenney, A., Wanger, G., et al. (2013). Microbial diversity in The Cedars, an ultrabasic, ultrareducing, and low salinity 
serpentinizing ecosystem. Proc. Natl. Acad. Sci. U.S.A. 110, 15336-15341. doi: $10.1073 /$ pnas. 1302426110

Suzuki, S., Kuenen, J. G., Schipper, K., Van Der Velde, S., Ishii, S. I., Wu, A., et al. (2014). Physiological and genomic features of highly alkaliphilic hydrogen-utilizing Betaproteobacteria from a continental serpentinizing site. Nat. Commun. 5, 3900-3900. doi: 10.1038/ncomms4900

Szponar, N., Brazelton, W. J., Schrenk, M. O., Bower, D. M., Steele, A., and Morrill, P. L. (2013). Geochemistry of a continental site of serpentinization, the Tablelands Ophiolite, Gros Morne National Park: a Mars analogue. Icarus 224, 286-296. doi: 10.1016/j.icarus.2012.07.004

Tanger, J. C., and Helgeson, H. C. (1988). Calculation of the thermodynamic and transport-properties of aqueous species at high-pressures and temperaturesrevised equations of state for the standard partial molal properties of ions and electrolytes. Am. J. Sci. 288, 19-98. doi: 10.2475/ajs.288.1.19

Tiago, I., and Verissimo, A. (2013). Microbial and functional diversity of a subterrestrial high $\mathrm{pH}$ groundwater associated to serpentinization. Environ. Microbiol. 15, 1687-1706. doi: 10.1111/1462-2920.12034

Viviano, C. E., Moersch, J. E., and McSween, H. Y. (2013). Implications for early hydrothermal environments on Mars through the spectral evidence for carbonation and chloritization reactions in the Nili Fossae region. J. Geophys. Res. Planets 118, 1858-1872. doi: 10.1002/jgre.20141

Wang, Y., Han, X., Jin, X., Qiu, Z., Ma, Z., and Yang, H. (2012). Hydrothermal Activity Events at Kairei Field, Central Indian Ridge 25 degrees S. Resour. Geol. 62, 208-214. doi: 10.1111/j.1751-3928.2012.00189.x

Whitman, W. B., Coleman, D. C., and Wiebe, W. J. (1998). Prokaryotes: the unseen majority. Proc. Natl. Acad. Sci. U.S.A. 95, 6578-6583. doi: 10.1073/pnas.95.12.6578
Wolery, T. J. (1992). EQ3NR, A Computer Program for Geochemical Aqueous Speciation-Solubility Calculations: Theoretical Manual, User's Guide, and Related Documentation (Version 7.0). Livermore, CA: Lawrence Livermore National Lab.

Woycheese, K., Meyer-Dombard, D. R., Cardace, D., Argayosa, A., and Arcilla, C. (2015). Out of the dark: transitional subsurface-to-surface microbial diversity in a terrestrial serpentinizing seep (Manleluag, Pangasinan, the Philippines). Front. Microbiol. 6:44. doi: 10.3389/fmicb.2015. 00044

Conflict of Interest Statement: The authors declare that the research was conducted in the absence of any commercial or financial relationships that could be construed as a potential conflict of interest.

Received: 31 August 2014; accepted: 05 January 2015; published online: 10 February 2015.

Citation: Cardace D, Meyer-Dombard DR, Woycheese KM and Arcilla CA (2015) Feasible metabolisms in high pH springs of the Philippines. Front. Microbiol. 6:10. doi: 10.3389/fmicb.2015.00010

This article was submitted to Extreme Microbiology, a section of the journal Frontiers in Microbiology.

Copyright (C) 2015 Cardace, Meyer-Dombard, Woycheese and Arcilla. This is an openaccess article distributed under the terms of the Creative Commons Attribution License (CC BY). The use, distribution or reproduction in other forums is permitted, provided the original author(s) or licensor are credited and that the original publication in this journal is cited, in accordance with accepted academic practice. No use, distribution or reproduction is permitted which does not comply with these terms. 